\title{
Supplements to: Cushion bog plant community responses to passive warming in southern Patagonia
}

Pancotto et al.

\section{Astelia pumila leaf properties}

Table S1. Areal number of plant individuals and amount of aboveground biomass. Sampling was performed on 29 and 30 April 2016 and therefore represent late growing season conditions. Conditions were recorded in $10 \mathrm{~cm}$ by $10 \mathrm{~cm}$ sampling rectangles in the warming treatment and control plots.

\begin{tabular}{rc|rrr|rrr} 
& & \multicolumn{5}{|c|}{ Sampling rectangle } & \\
Plot & Treatment & Dimensions, cm & Area, m2 & Number of plants & Weight, g & Dry weight, g \\
\hline 10 & Warming & 8 & 9 & 0.0072 & 44 & 12.363 & 2.688 \\
11 & Warming & 10 & 9.5 & 0.0095 & 45 & 15.676 & 3.308 \\
12 & Warming & 9.5 & 9.5 & 0.009025 & 53 & 20.794 & 3.758 \\
13 & Warming & 11.5 & 8 & 0.0092 & 43 & 24.789 & 4.570 \\
14 & Warming & 10.5 & 10 & 0.0105 & 67 & 13.489 & 2.811 \\
15 & Warming & 10 & 8 & 0.008 & 37 & 8.357 & 1.745 \\
16 & Warming & 8.5 & 8 & 0.0068 & 66 & 17.873 & 3.762 \\
17 & Warming & 9 & 10 & 0.009 & 57 & 14.970 & 2.914 \\
18 & Warming & 9 & 11 & 0.0099 & 59 & 19.450 & 4.018 \\
19 & Warming & 9.5 & 8 & 0.0076 & 39 & 21.038 & 4.204 \\
20 & Control & 10.5 & 8 & 0.0084 & 53 & 20.398 & 4.177 \\
21 & Control & 9 & 9 & 0.0081 & 54 & 15.706 & 3.058 \\
22 & Control & 10 & 9 & 0.009 & 47 & 13.016 & 2.432 \\
23 & Control & 9 & 8.5 & 0.00765 & 56 & 23.337 & 4.47 \\
24 & Control & 5 & 8 & 0.004 & 25 & 8.342 & 1.871 \\
25 & Control & 9 & 9 & 0.0081 & 65 & 14.473 & 3.081 \\
26 & Control & 9 & 8.5 & 0.00765 & 61 & 15.013 & 3.069 \\
27 & Control & 8.5 & 6 & 0.0051 & 34 & 11.092 & 2.276 \\
28 & Control & 8.5 & 9 & 0.00765 & 39 & 20.153 & 3.889 \\
29 & Control & 8 & 7.5 & 0.006 & 37 & 15.268 & 2.798
\end{tabular}




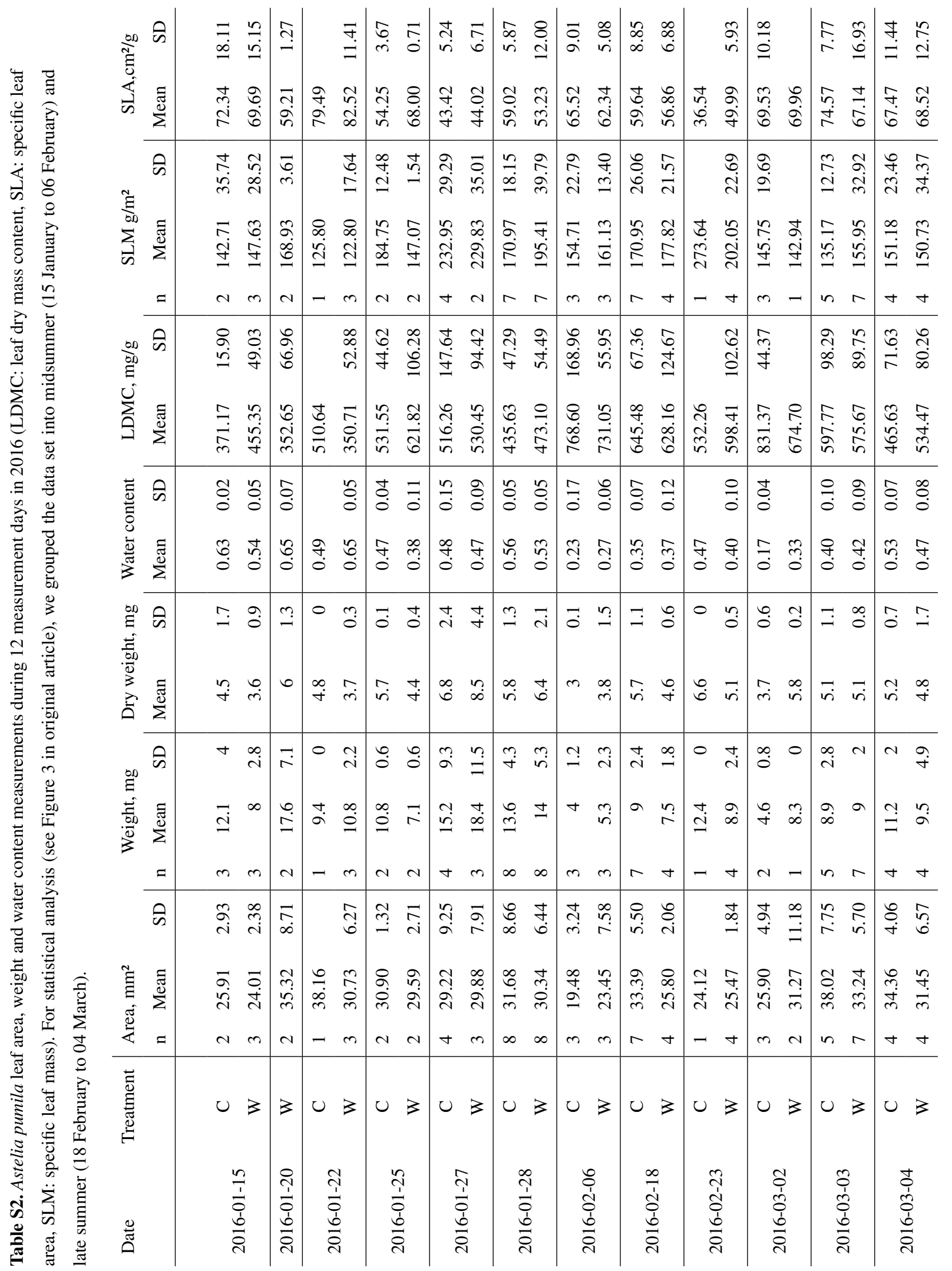




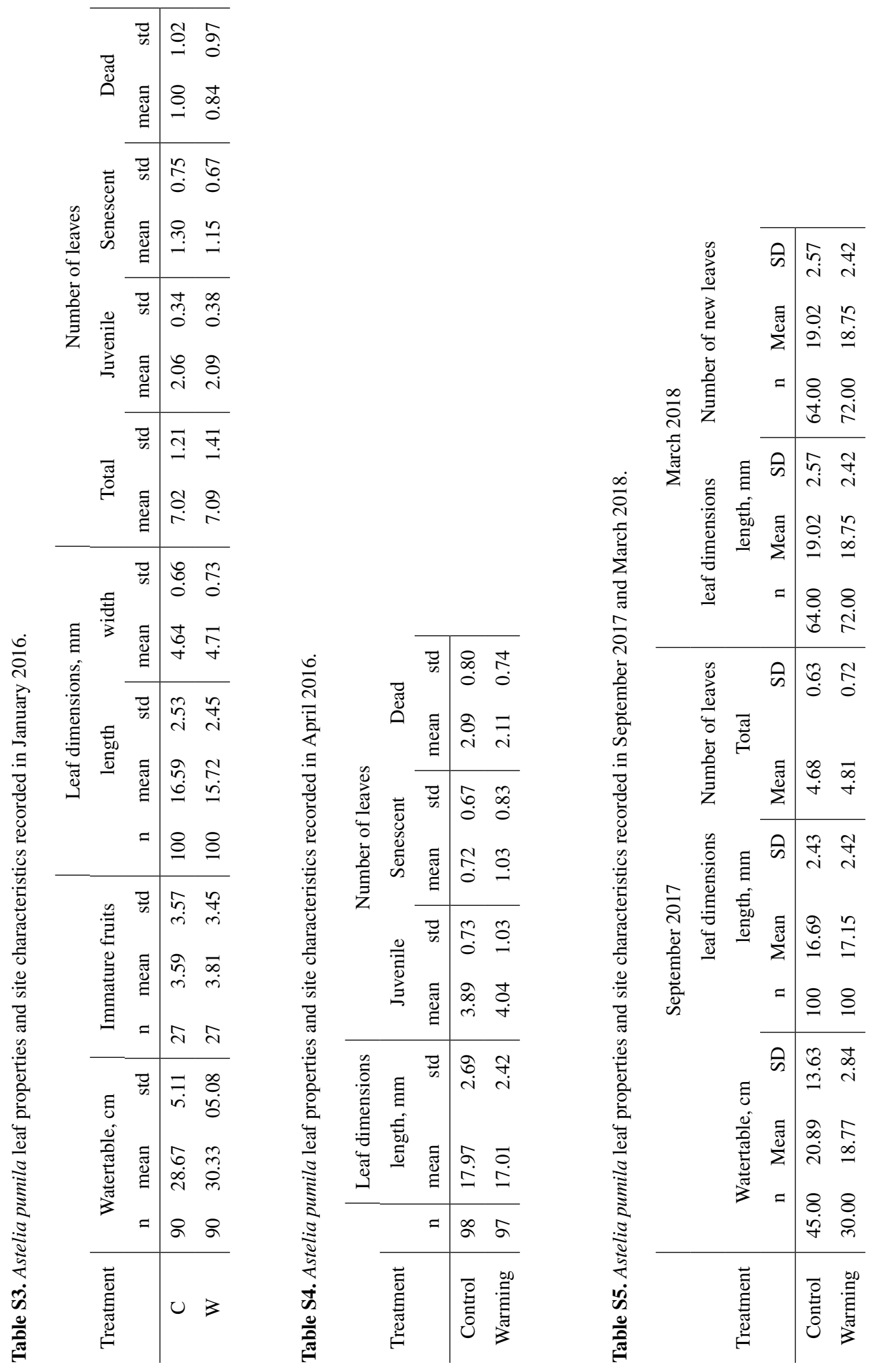


Table S6. Spectrophotometrically derived leaf chlorophyll and carotene contents.

\begin{tabular}{|c|c|c|c|c|c|c|c|c|c|c|c|c|}
\hline \multirow[b]{2}{*}{ Date } & \multirow[b]{2}{*}{ Treatment } & \multirow[b]{2}{*}{$\mathrm{n}$} & \multicolumn{2}{|c|}{$\begin{array}{c}\text { Chlorophyll a } \\
\text { per dry mass, mg/g }\end{array}$} & \multicolumn{2}{|c|}{$\begin{array}{c}\text { Chlorophyll b } \\
\text { per dry mass, mg/g }\end{array}$} & \multicolumn{2}{|c|}{$\begin{array}{l}\text { Total chlorophyll } \\
\text { per dry mass, mg/g }\end{array}$} & \multicolumn{2}{|c|}{$\begin{array}{l}\text { Chlorophyll a/ } \\
\text { Chlorophyll b }\end{array}$} & \multicolumn{2}{|c|}{$\begin{array}{c}\text { Carotene } \\
\text { per dry mass, } \mathrm{mg} / \mathrm{g}\end{array}$} \\
\hline & & & Mean & SD & Mean & SD & Mean & SD & Mean & SD & Mean & $\mathrm{SD}$ \\
\hline \multirow{2}{*}{29 January 2016} & Control & 4 & 2.17 & 0.66 & 0.58 & 0.14 & 1.59 & 0.55 & 3.71 & 0.54 & 0.67 & 0.22 \\
\hline & Warming & 5 & 2.76 & 0.4 & 0.74 & 0.15 & 2.02 & 0.28 & 3.79 & 0.38 & 0.82 & 0.08 \\
\hline \multirow{2}{*}{13 February 2016} & Control & 6 & 1.87 & 0.37 & 0.84 & 0.12 & 1.03 & 0.26 & 2.21 & 0.15 & 0.43 & 0.07 \\
\hline & Warming & 6 & 1.69 & 0.34 & 0.76 & 0.1 & 0.92 & 0.26 & 2.2 & 0.26 & 0.4 & 0.1 \\
\hline \multirow{2}{*}{2 May 2016} & Control & 10 & 2.58 & 0.28 & 0.71 & 0.11 & 3.28 & 0.38 & 3.68 & 0.24 & 0.69 & 0.06 \\
\hline & Warming & 10 & 2.56 & 0.72 & 0.75 & 0.18 & 3.31 & 0.88 & 3.41 & 0.51 & 0.67 & 0.19 \\
\hline \multirow{2}{*}{24 November 2016} & Control & 10 & 3.74 & 0.96 & 1.11 & 0.32 & 4.85 & 1.27 & 2.02 & 0.49 & 1.29 & 0.35 \\
\hline & Warming & 10 & 3.98 & 0.67 & 1.25 & 0.25 & 5.22 & 0.91 & 2.1 & 0.56 & 1.3 & 0.25 \\
\hline \multirow{2}{*}{28 September 2017} & Control & 10 & 2.68 & 0.37 & 0.73 & 0.11 & 3.41 & 0.46 & 3.69 & 0.28 & 0.97 & 0.16 \\
\hline & Warming & 10 & 2.91 & 0.82 & 0.88 & 0.34 & 3.79 & 1.14 & 3.42 & 0.55 & 1.03 & 0.26 \\
\hline
\end{tabular}




\section{Seasonally averaged diurnal air and soil temperature cycles}

September, October, November
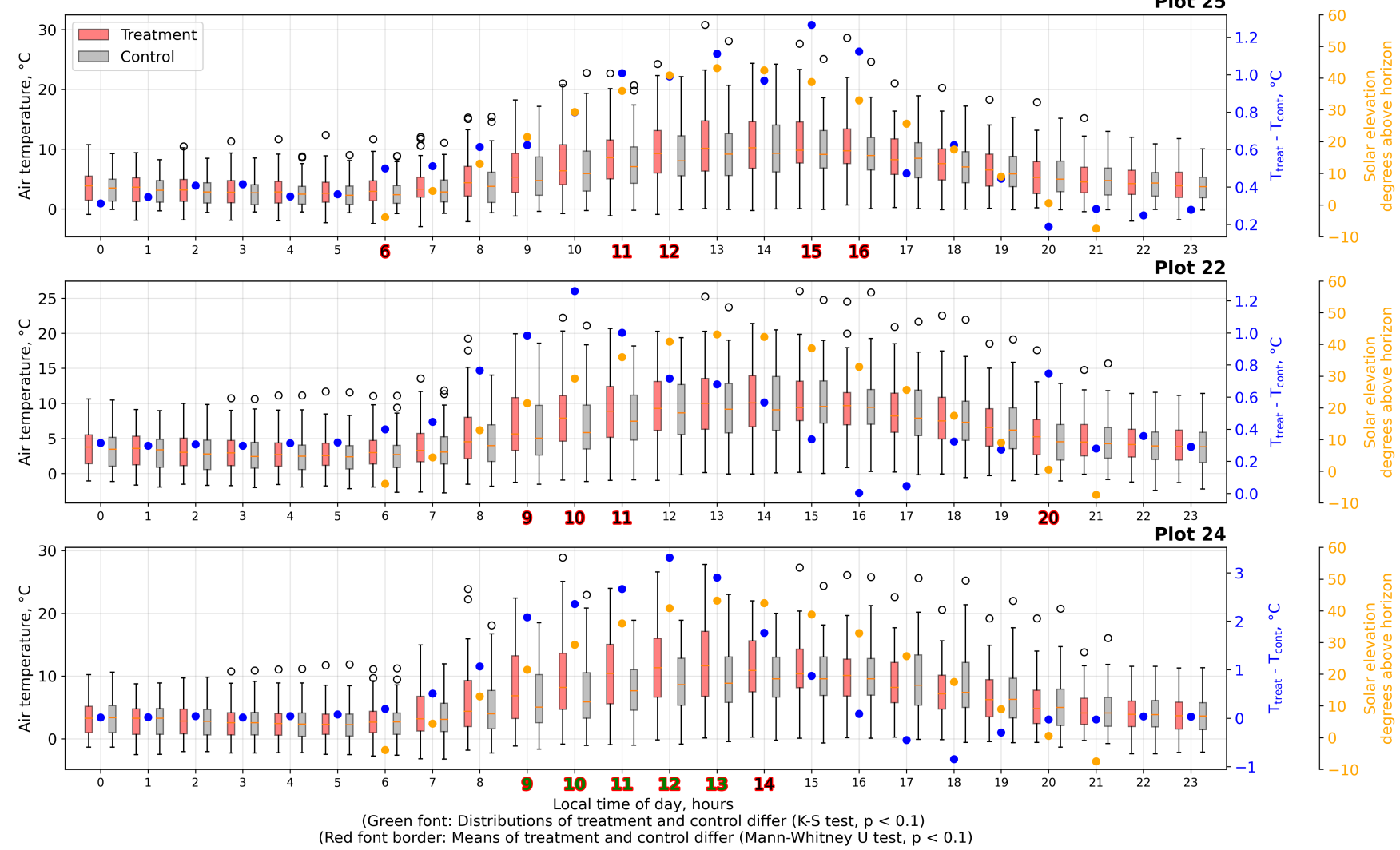

Figure S1. Average diurnal air temperature $\left(1 \mathrm{~cm}\right.$ above canopy) cycle at the treatment $\left(\mathrm{T}_{\text {treat }}\right)$ and control $\left(\mathrm{T}_{\text {cont }}\right)$ plots in spring for the measurement period from January 2018 to January 2019. 
December, January, February
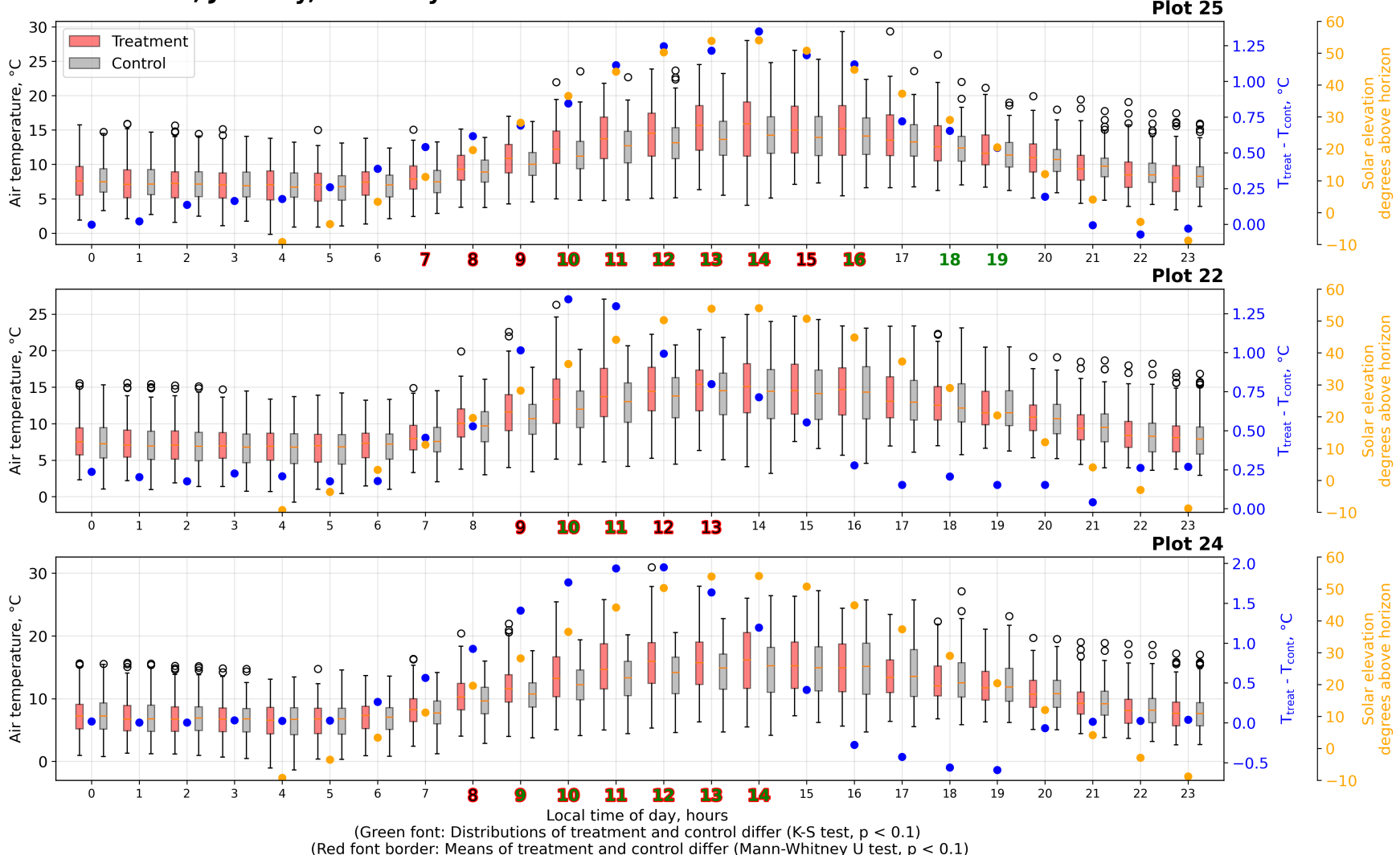

Figure S2. Average diurnal air temperature $\left(1 \mathrm{~cm}\right.$ above canopy) cycle at the treatment $\left(\mathrm{T}_{\text {treat }}\right)$ and control $\left(\mathrm{T}_{\text {cont }}\right)$ plots in summer for the measurement period from January 2018 to January 2019. 
March, April, May
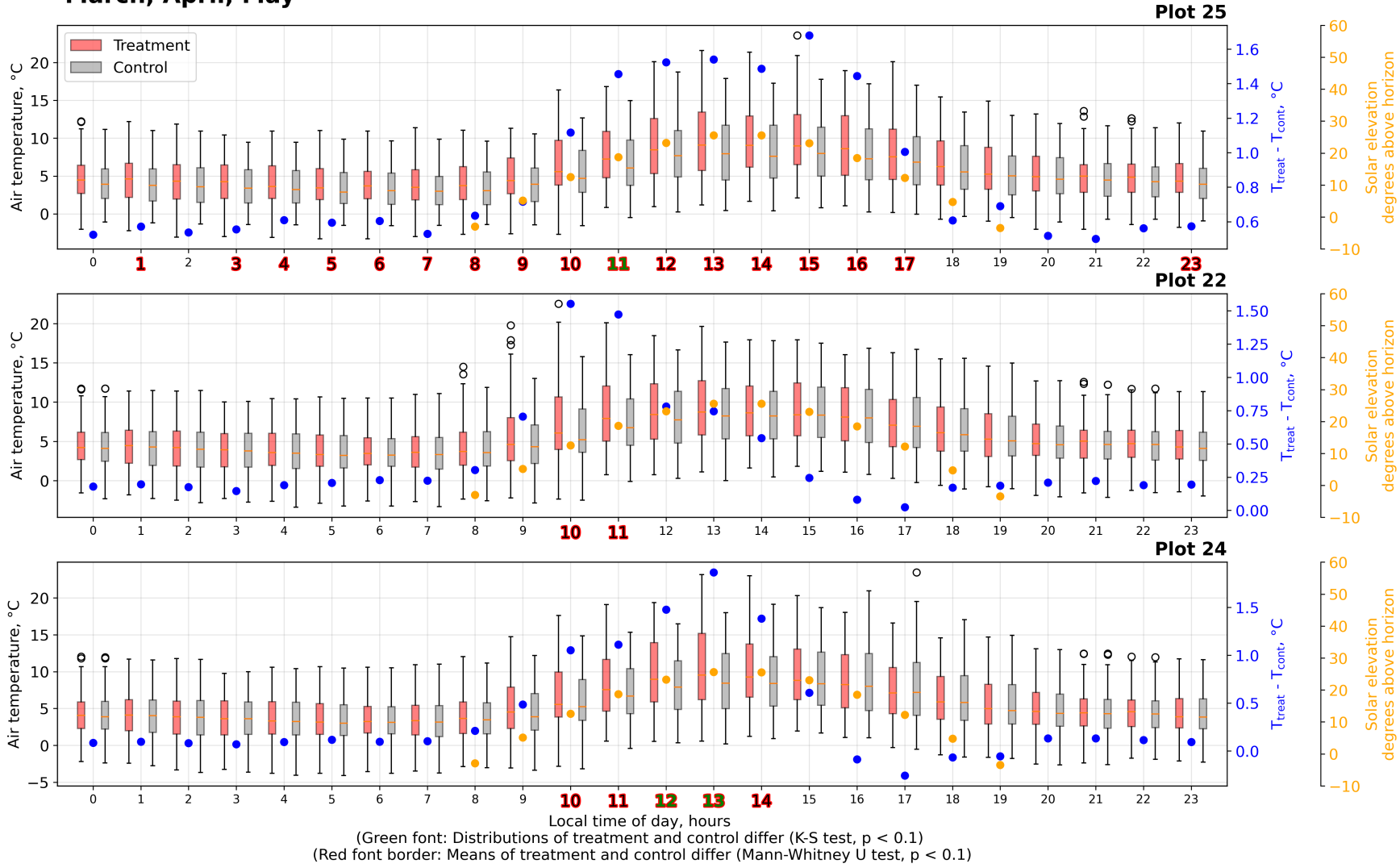

Figure S3. Average diurnal air temperature $\left(1 \mathrm{~cm}\right.$ above canopy) cycle at the treatment $\left(\mathrm{T}_{\text {treat }}\right)$ and control ( $\left.\mathrm{T}_{\text {cont }}\right)$ plots in autumn for the measurement period from January 2018 to January 2019. 
June, July, August
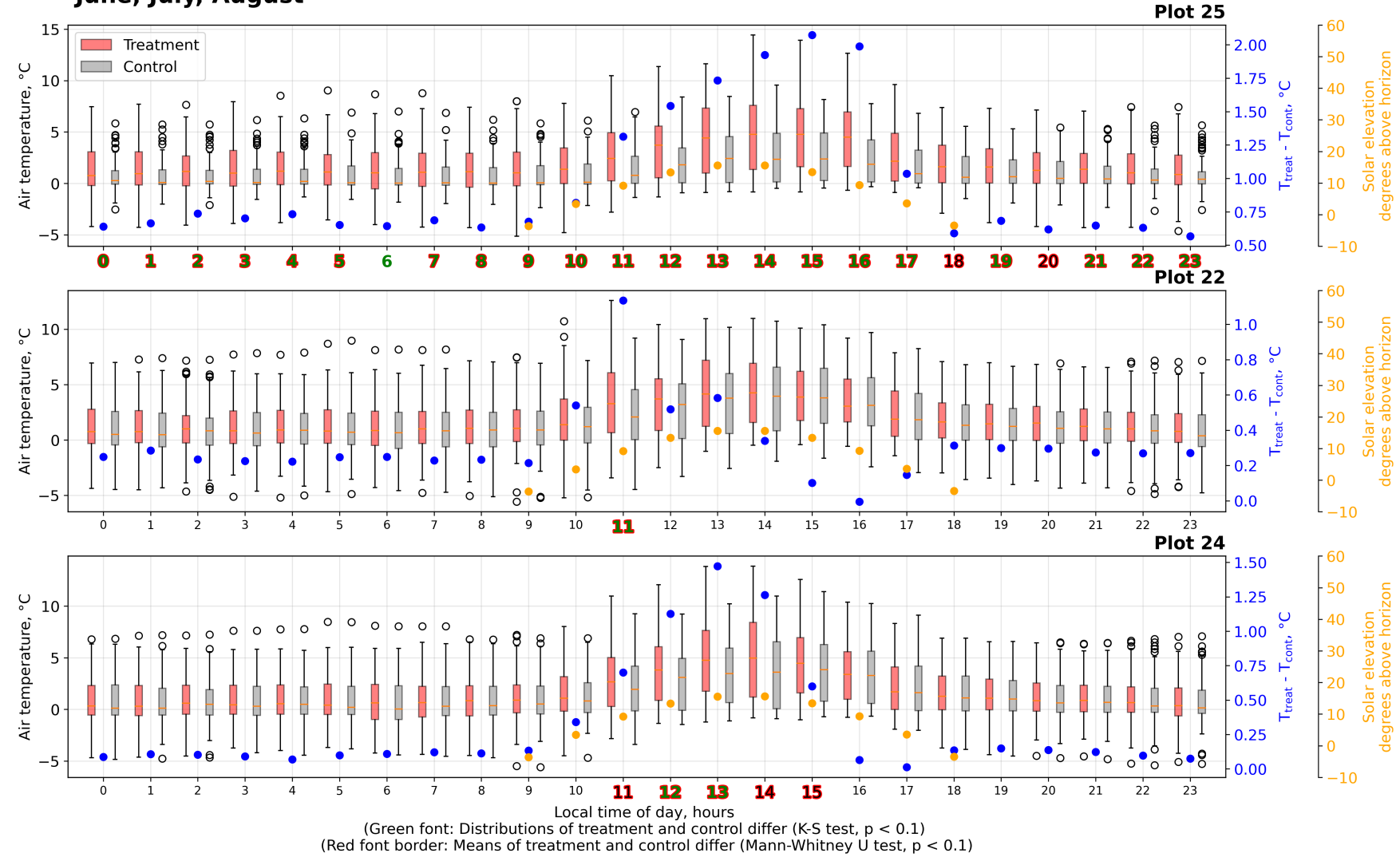

Figure S4. Average diurnal air temperature $\left(1 \mathrm{~cm}\right.$ above canopy) cycle at the treatment $\left(\mathrm{T}_{\text {treat }}\right)$ and control $\left(\mathrm{T}_{\text {cont }}\right)$ plots in winter for the measurement period from January 2018 to January 2019. 
September, October, November
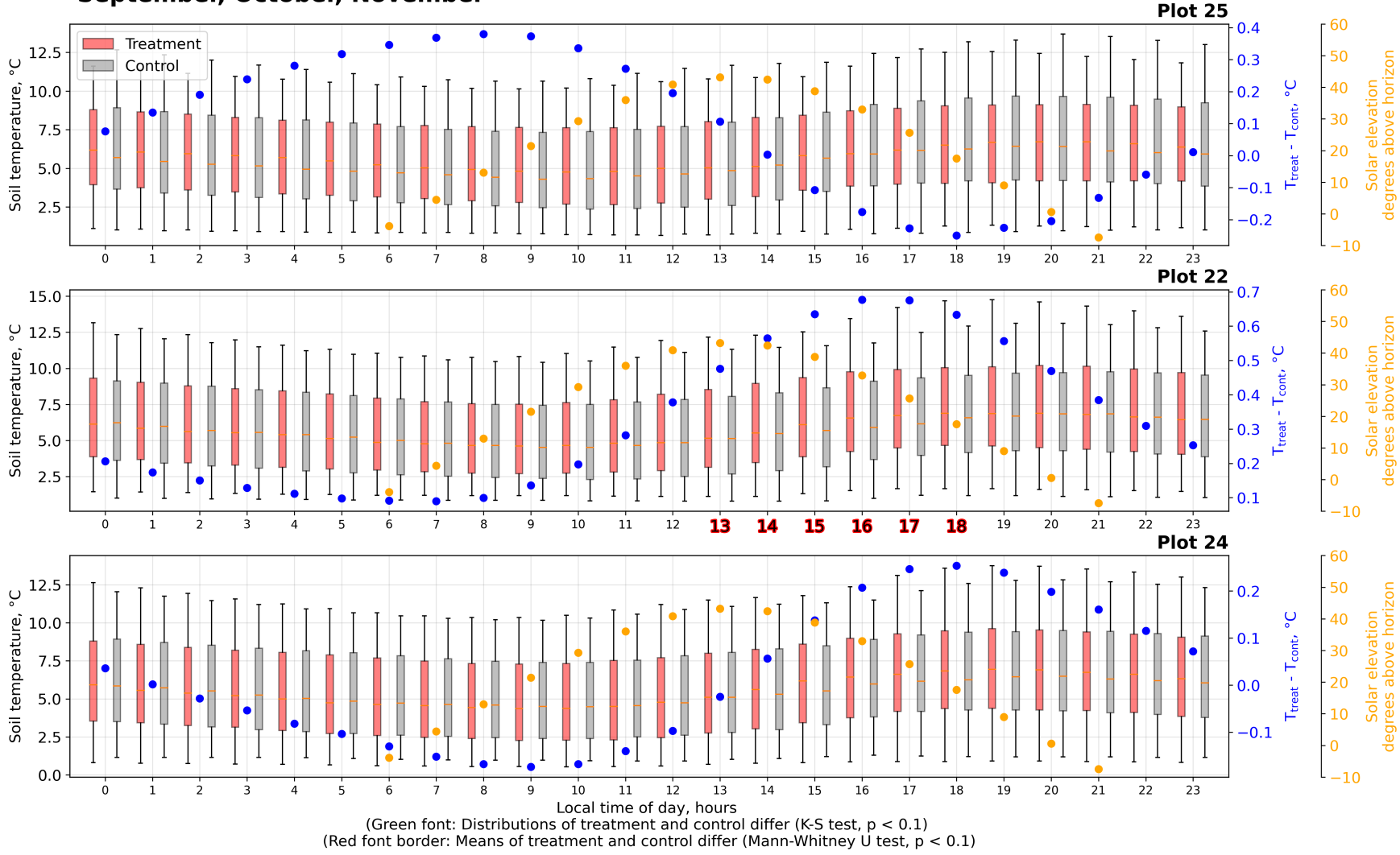

Figure S5. Average diurnal soil temperature $(10 \mathrm{~cm}$ depth $)$ cycle at the treatment $\left(\mathrm{T}_{\text {treat }}\right)$ and control $\left(\mathrm{T}_{\text {cont }}\right)$ plots in spring for the measurement period from January 2018 to January 2019. 
December, January, February
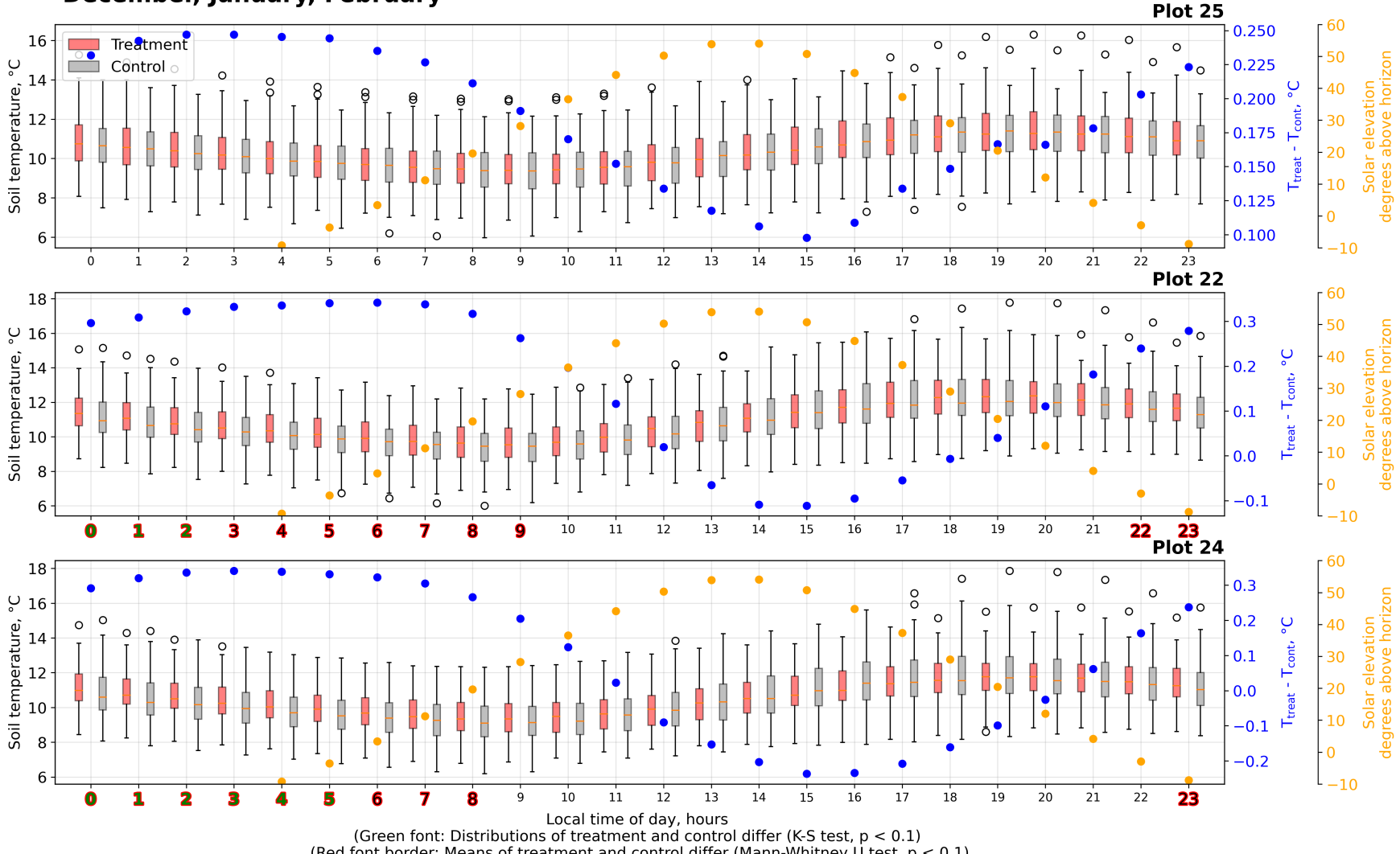

Figure S6. Average diurnal soil temperature $\left(10 \mathrm{~cm}\right.$ depth) cycle at the treatment $\left(\mathrm{T}_{\text {treat }}\right)$ and control $\left(\mathrm{T}_{\text {cont }}\right)$ plots in summer for the measurement period from January 2018 to January 2019. 
March, April, May
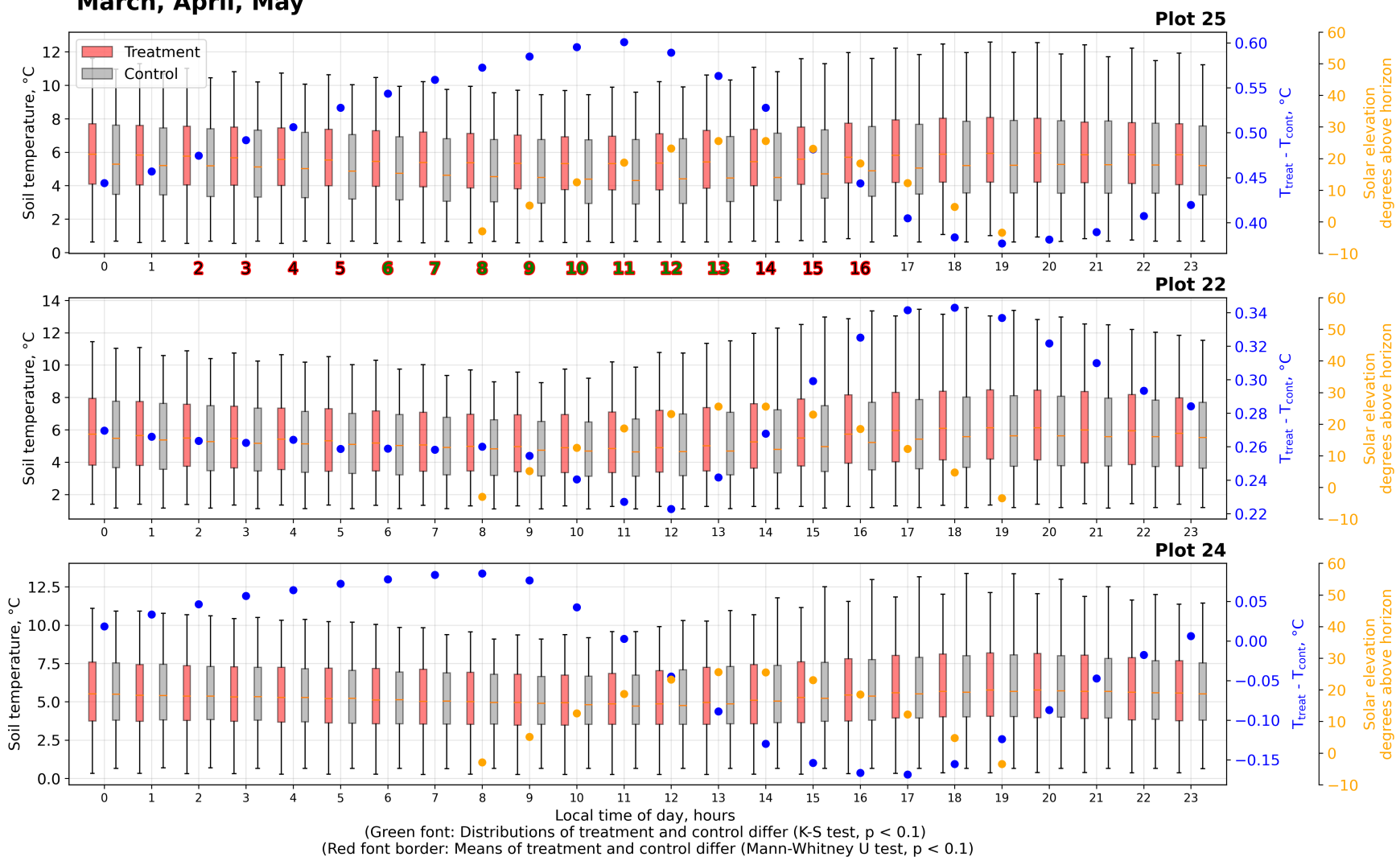

Figure S7. Average diurnal soil temperature $\left(10 \mathrm{~cm}\right.$ depth) cycle at the treatment $\left(\mathrm{T}_{\text {treat }}\right)$ and control $\left(\mathrm{T}_{\text {cont }}\right)$ plots in autumn for the measurement period from January 2018 to January 2019. 
June, July, August

Plot 25
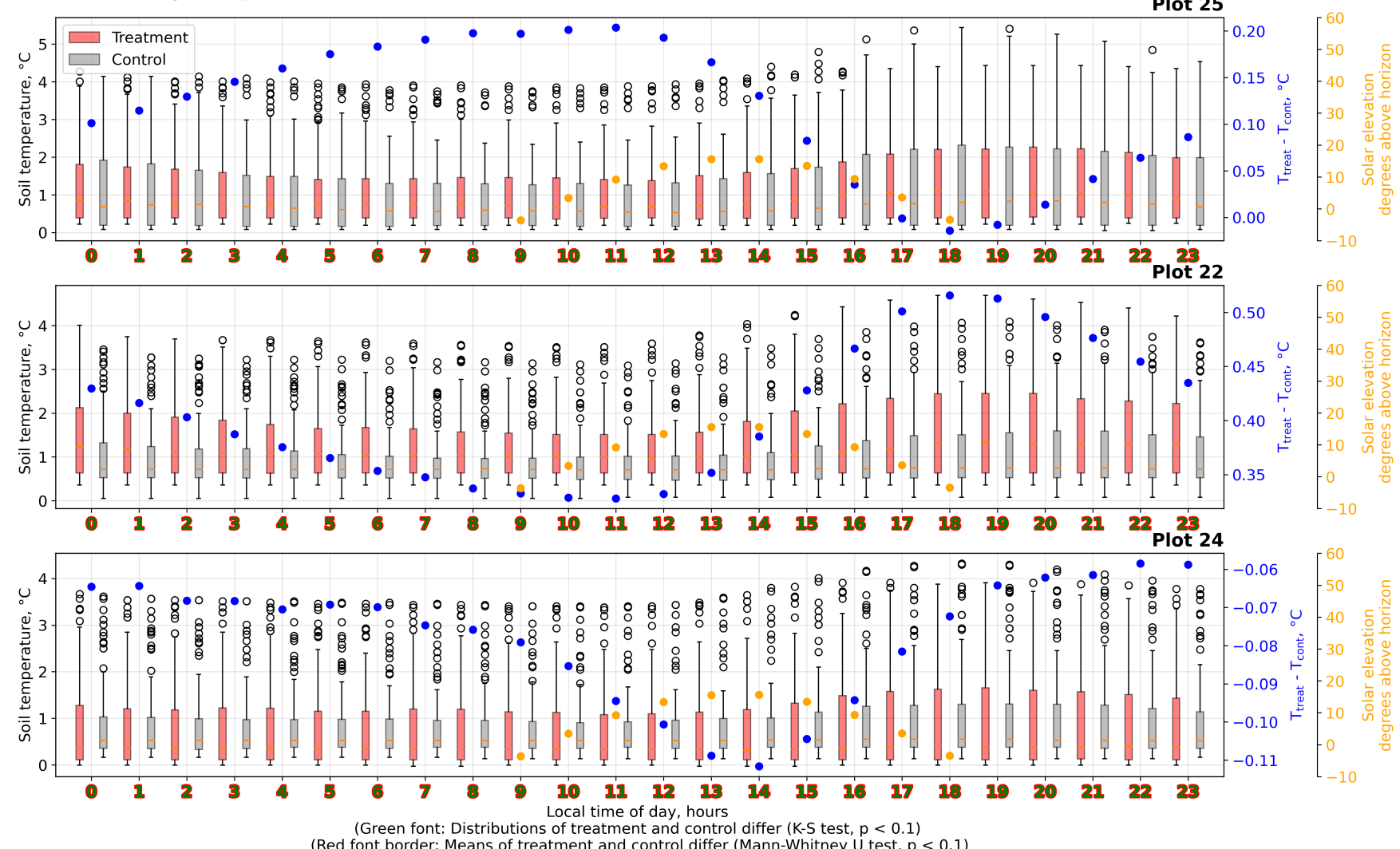

Figure S8. Average diurnal soil temperature $(10 \mathrm{~cm}$ depth $)$ cycle at the treatment $\left(\mathrm{T}_{\text {treat }}\right)$ and control $\left(\mathrm{T}_{\text {cont }}\right)$ plots in winter for the measurement period from January 2018 to January 2019. 


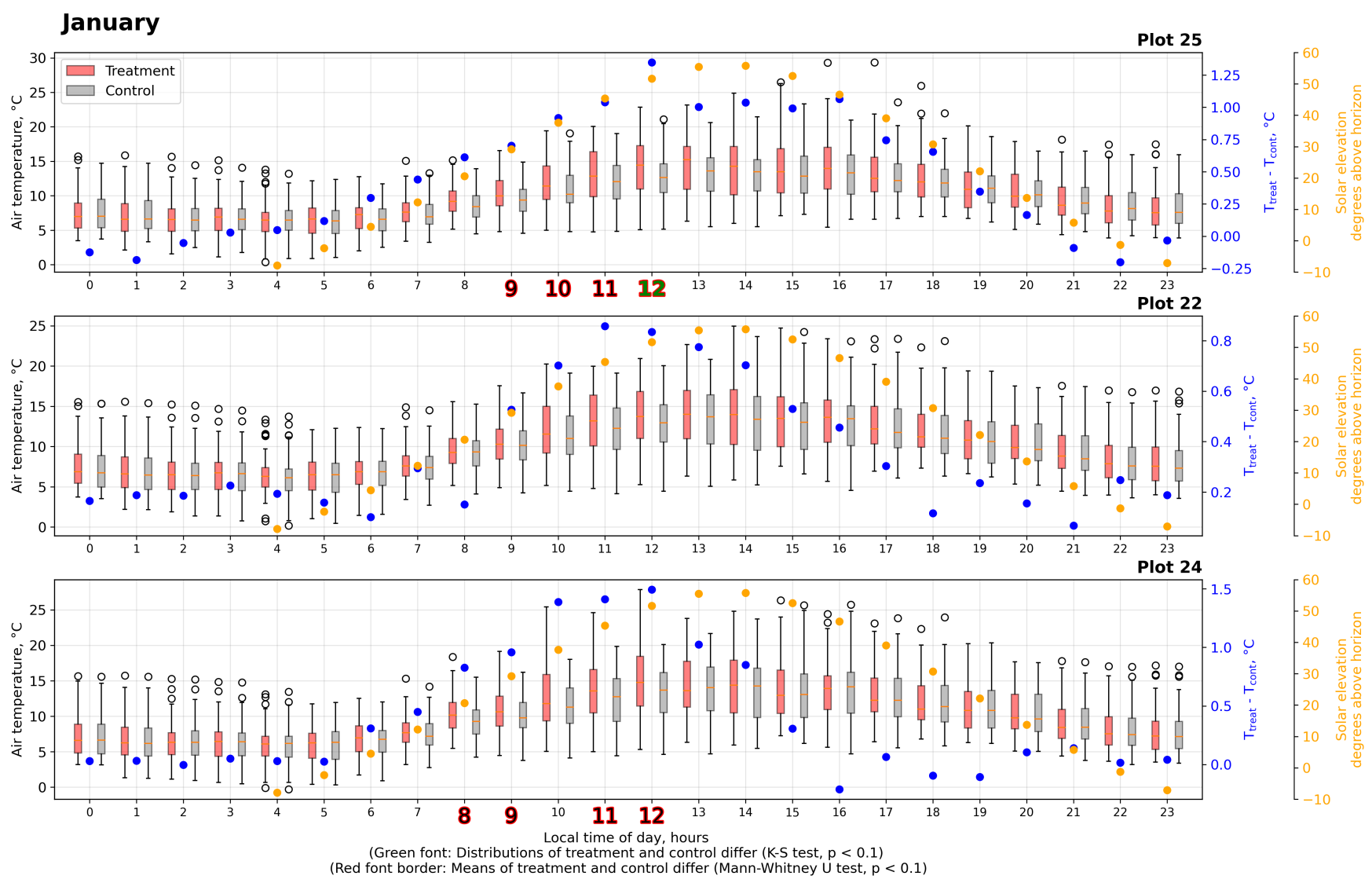

Figure S9. Average diurnal air temperature $\left(1 \mathrm{~cm}\right.$ above canopy) cycle at the treatment $\left(\mathrm{T}_{\text {treat }}\right)$ and control $\left(\mathrm{T}_{\text {cont }}\right)$ plots in January 2018 and January 2019. 

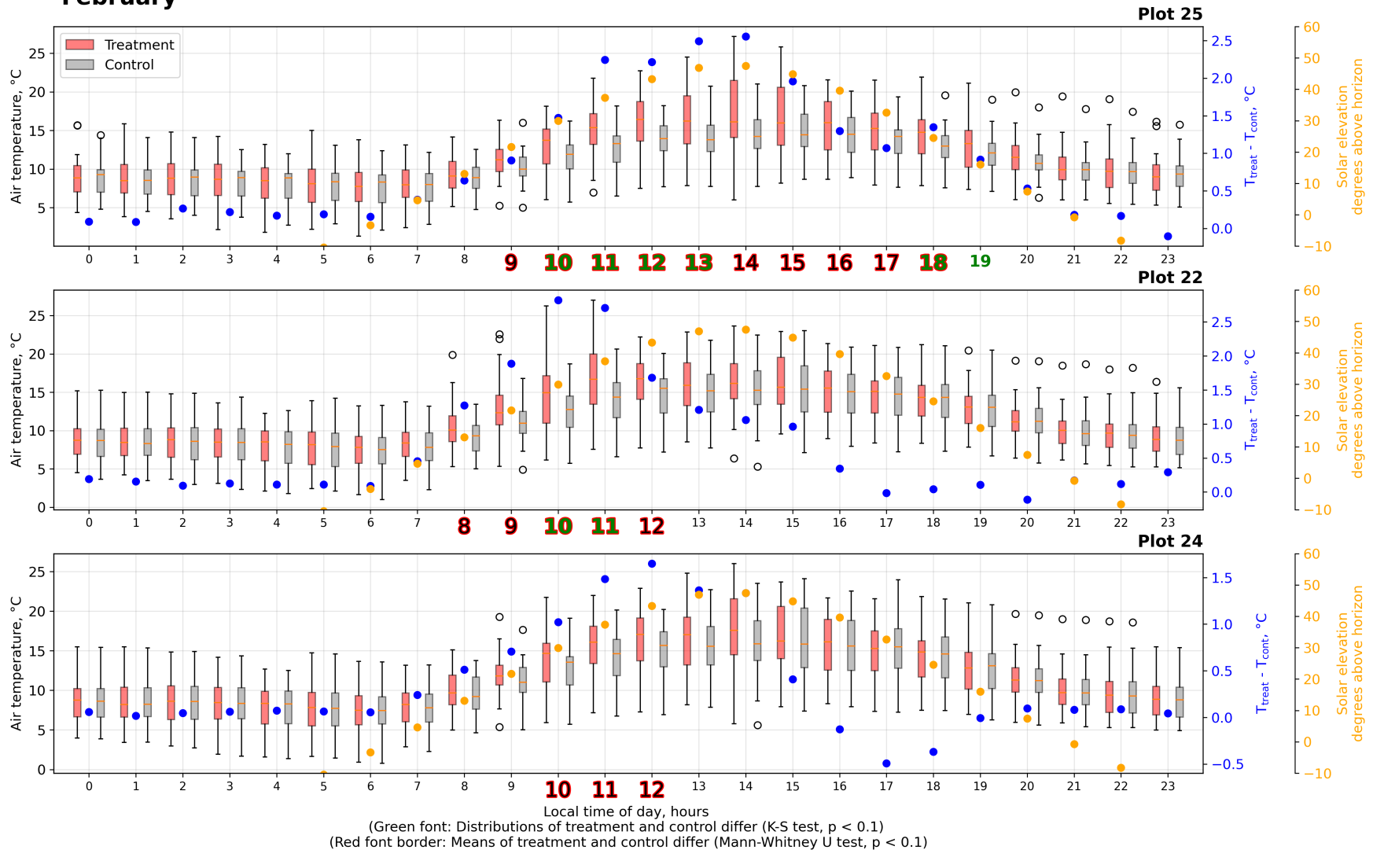

Figure S10. Average diurnal air temperature $\left(1 \mathrm{~cm}\right.$ above canopy) cycle at the treatment $\left(\mathrm{T}_{\text {treat }}\right)$ and control $\left(\mathrm{T}_{\text {cont }}\right)$ plots in February 2018. 
March
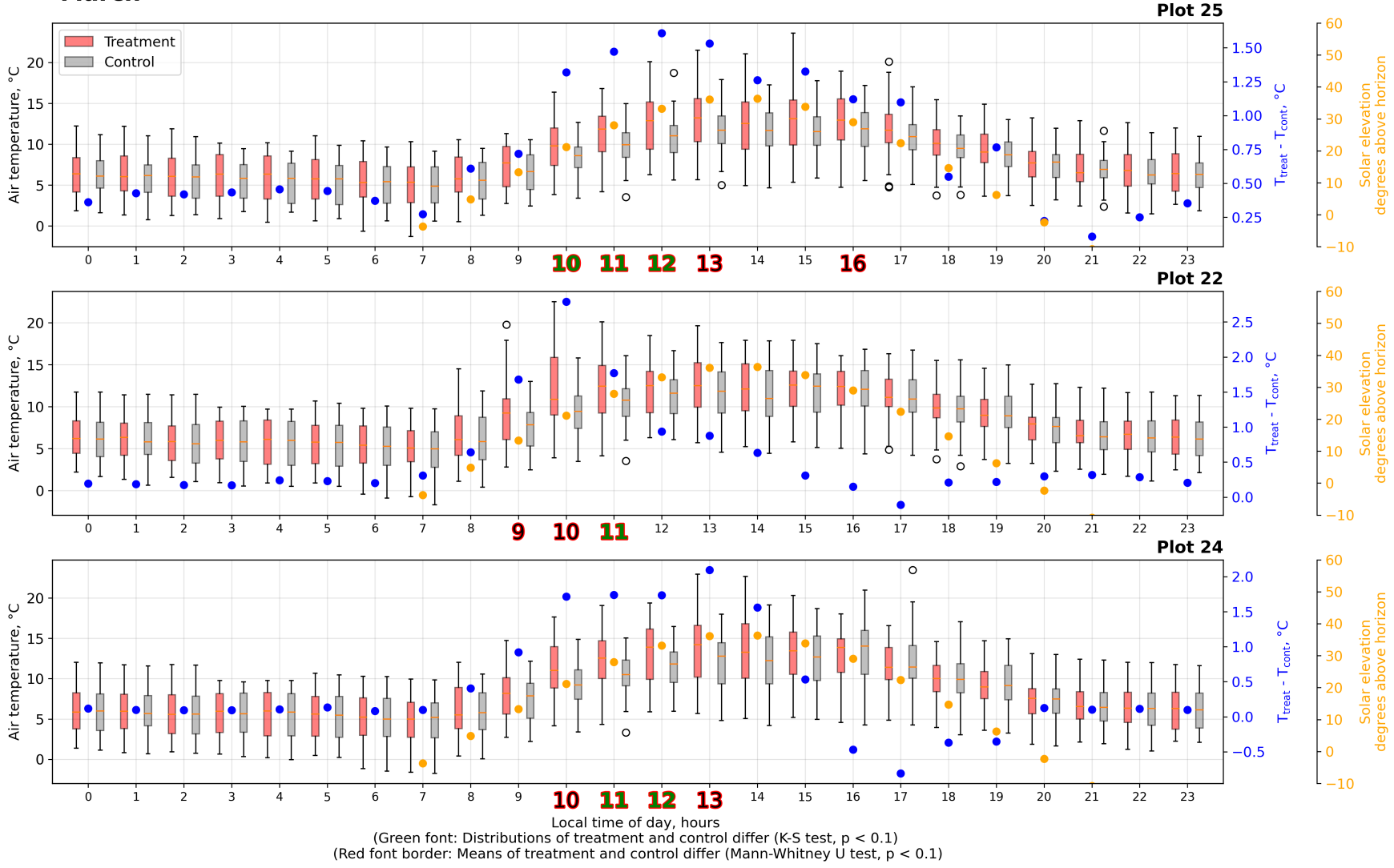

Figure S11. Average diurnal air temperature $\left(1 \mathrm{~cm}\right.$ above canopy) cycle at the treatment $\left(\mathrm{T}_{\text {treat }}\right)$ and control $\left(\mathrm{T}_{\text {cont }}\right)$ plots in March 2018. 


\section{April}
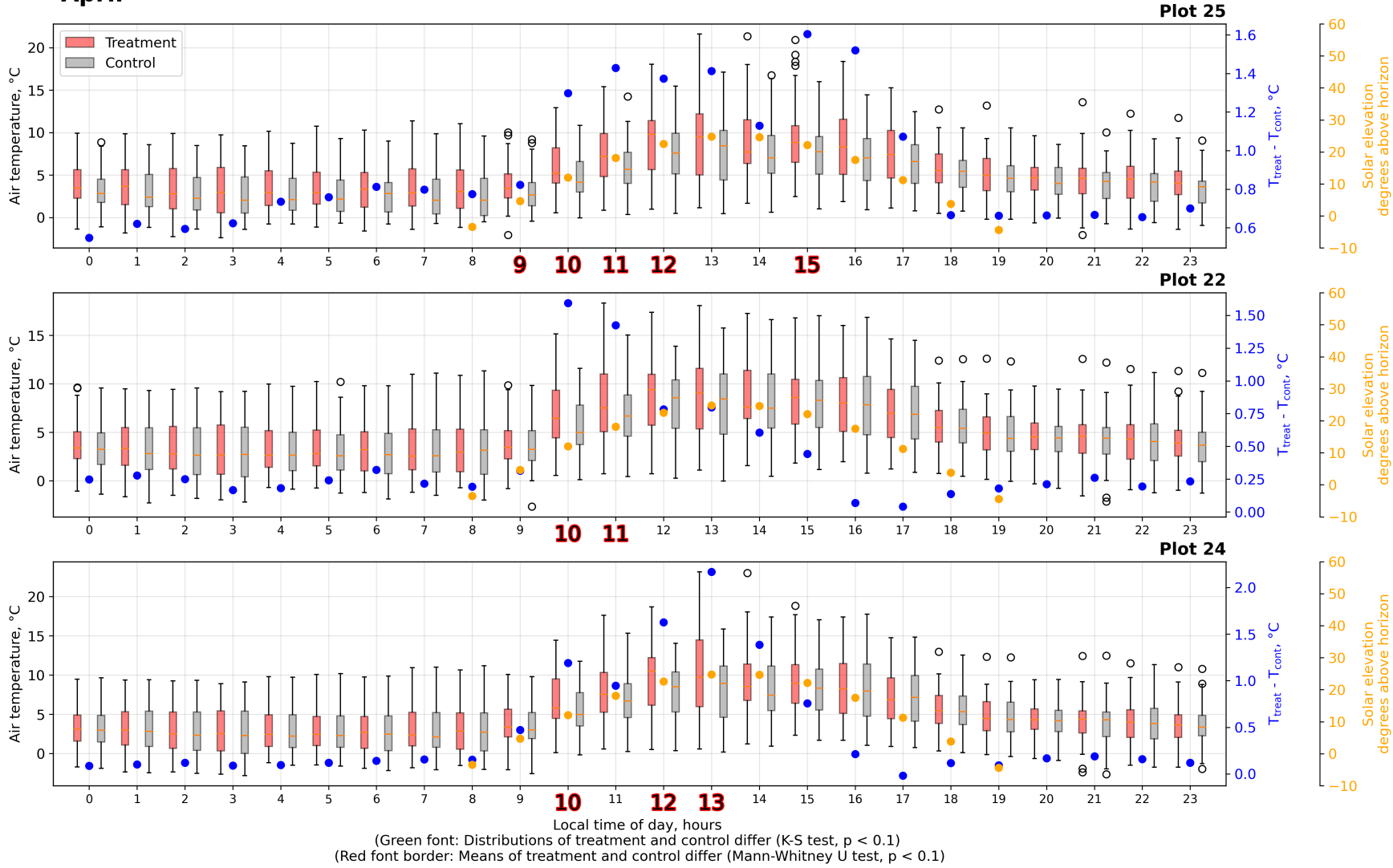

Figure S12. Average diurnal air temperature (1 cm above canopy) cycle at the treatment $\left(\mathrm{T}_{\text {treat }}\right)$ and control $\left(\mathrm{T}_{\text {cont }}\right)$ plots in April 2018. 


\section{May}
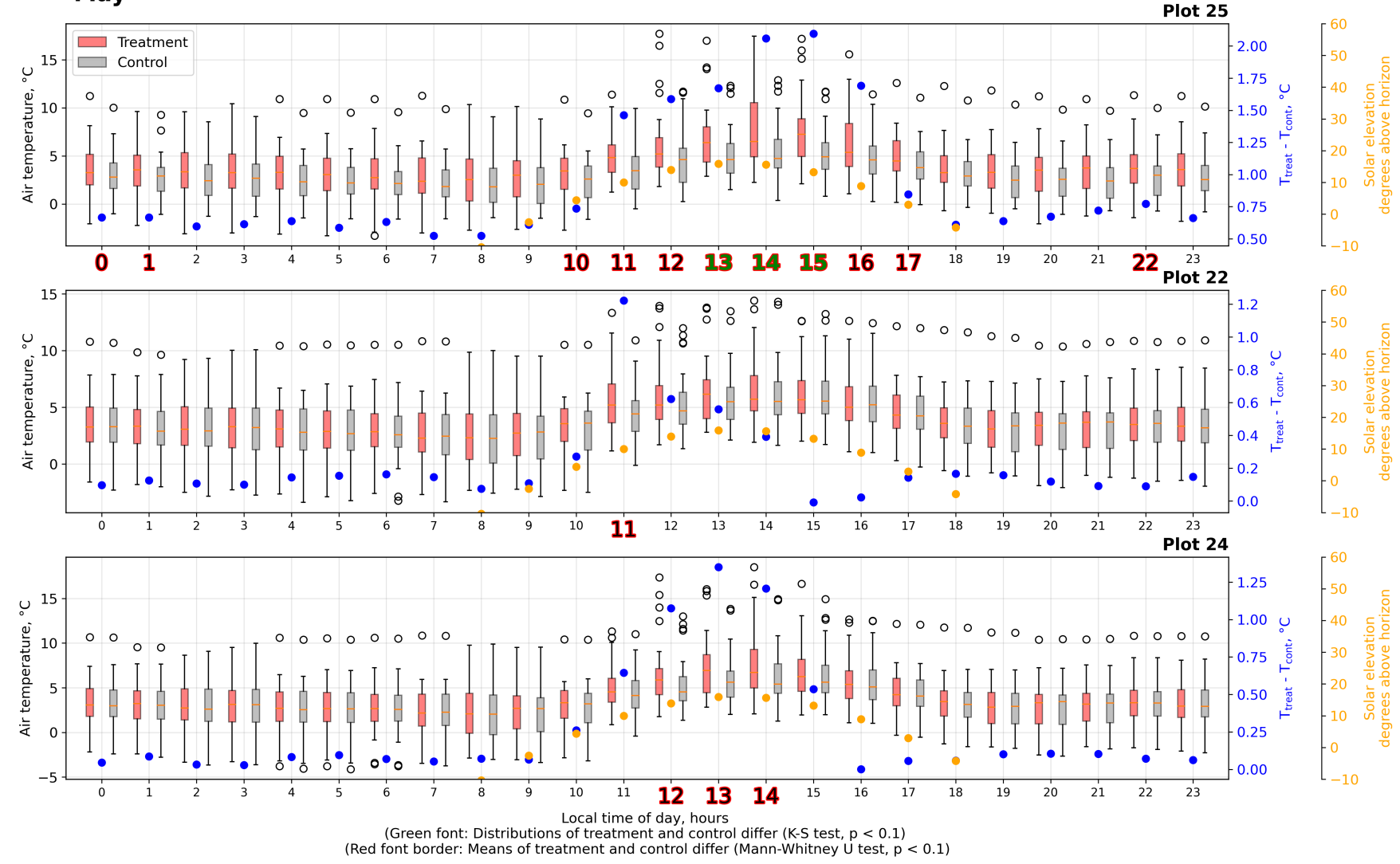

Figure S13. Average diurnal air temperature (1 cm above canopy) cycle at the treatment $\left(\mathrm{T}_{\text {treat }}\right)$ and control $\left(\mathrm{T}_{\text {cont }}\right)$ plots in May 2018. 


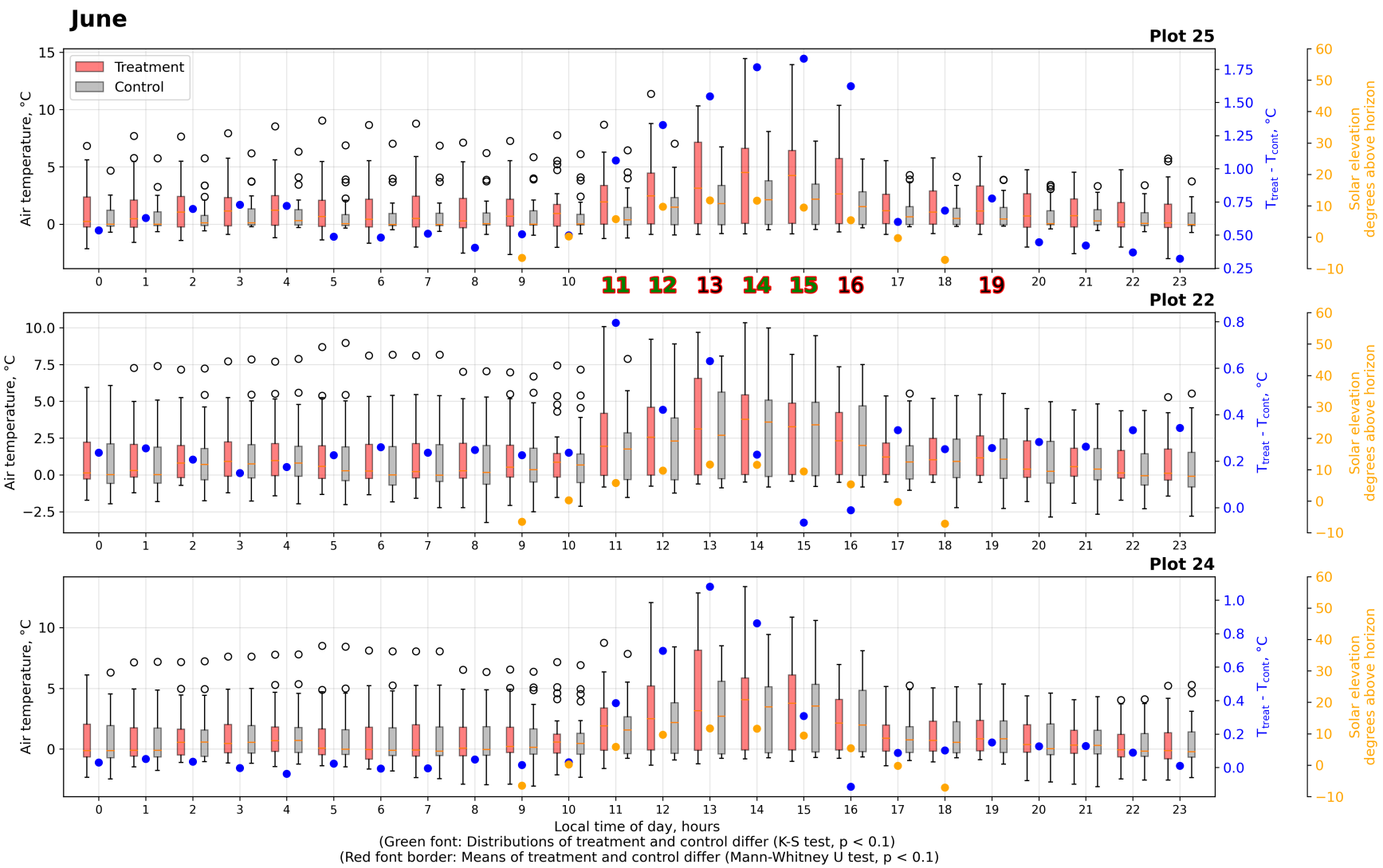

Figure S14. Average diurnal air temperature (1 cm above canopy) cycle at the treatment $\left(\mathrm{T}_{\text {treat }}\right)$ and control $\left(\mathrm{T}_{\text {cont }}\right)$ plots in June 2018. 

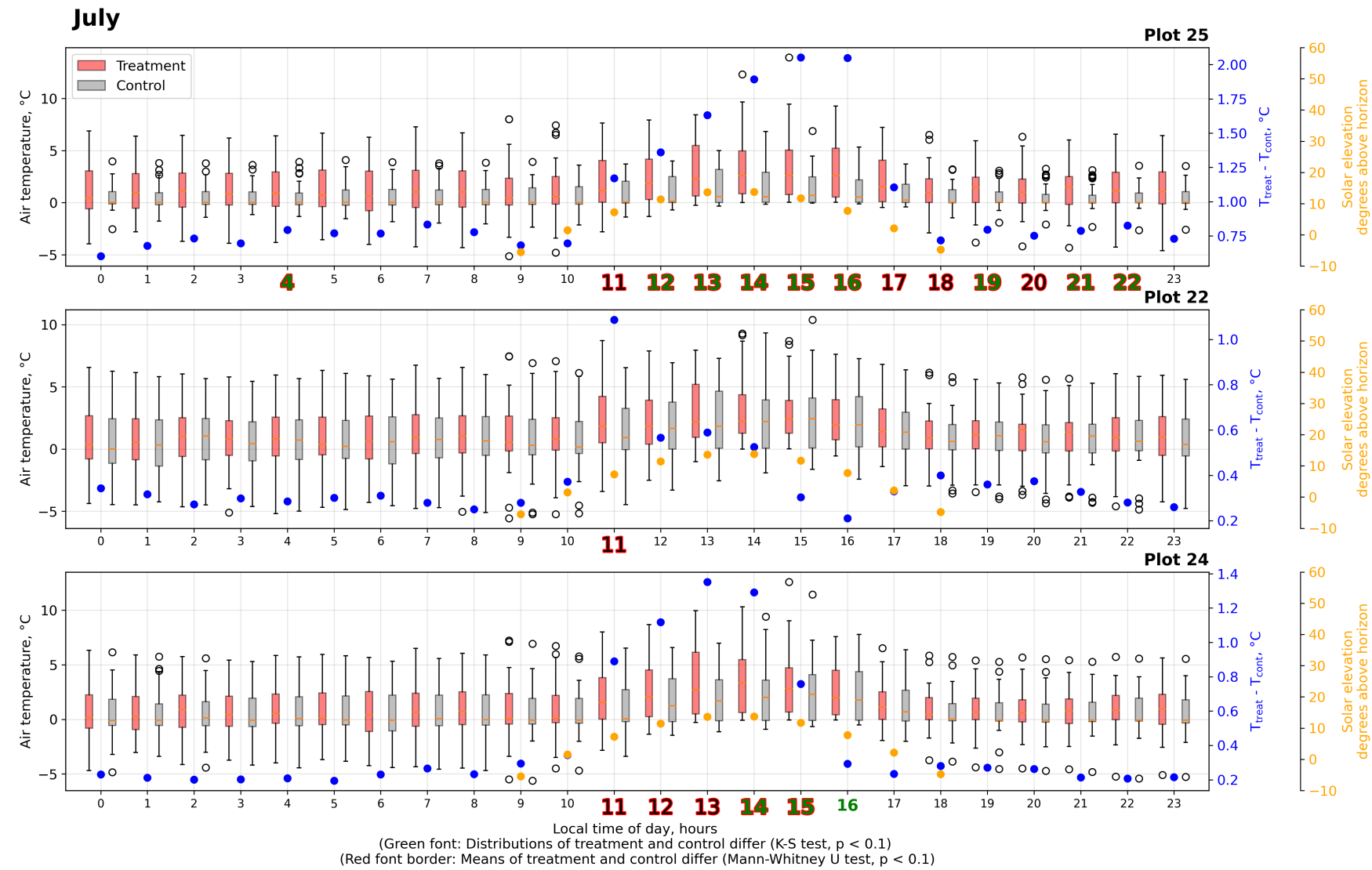

Figure S15. Average diurnal air temperature $\left(1 \mathrm{~cm}\right.$ above canopy) cycle at the treatment $\left(\mathrm{T}_{\text {treat }}\right)$ and control $\left(\mathrm{T}_{\text {cont }}\right)$ plots in July 2018. 

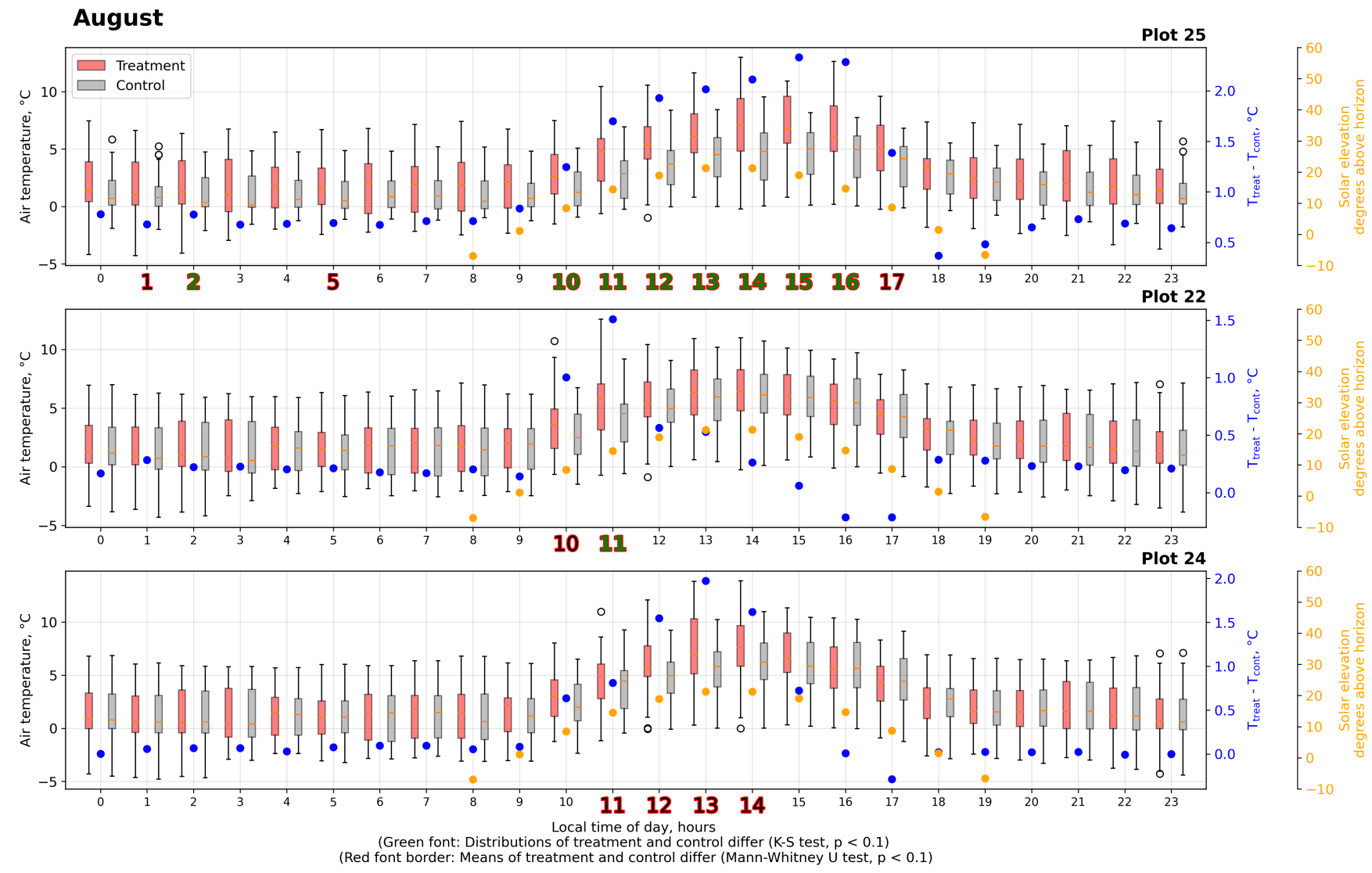

Figure S16. Average diurnal air temperature $\left(1 \mathrm{~cm}\right.$ above canopy) cycle at the treatment $\left(\mathrm{T}_{\text {treat }}\right)$ and control $\left(\mathrm{T}_{\text {cont }}\right)$ plots in August 2018. 


\section{September}
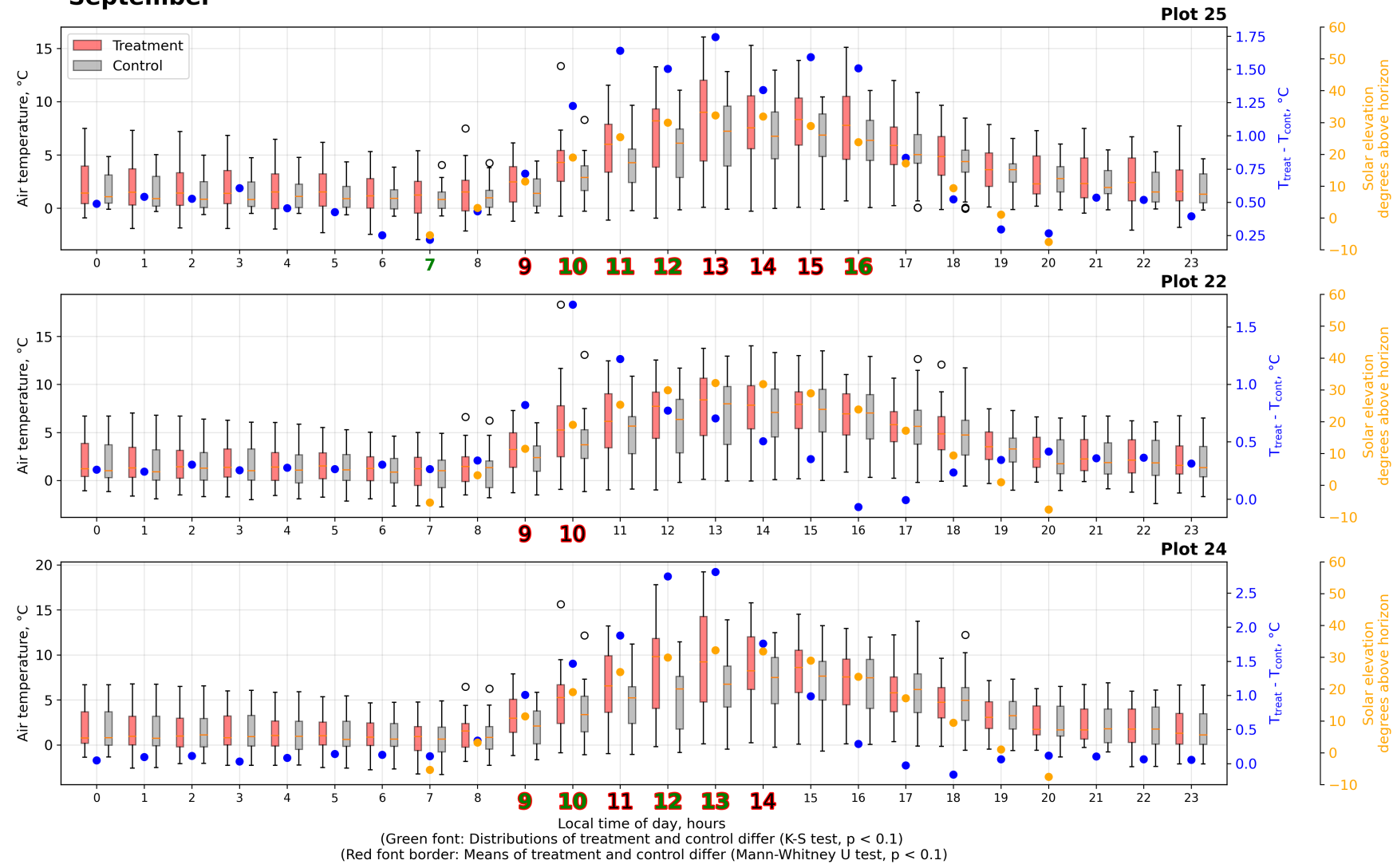

Figure S17. Average diurnal air temperature $\left(1 \mathrm{~cm}\right.$ above canopy) cycle at the treatment $\left(\mathrm{T}_{\text {treat }}\right)$ and control $\left(\mathrm{T}_{\text {cont }}\right)$ plots in September 2018. 


\section{October}
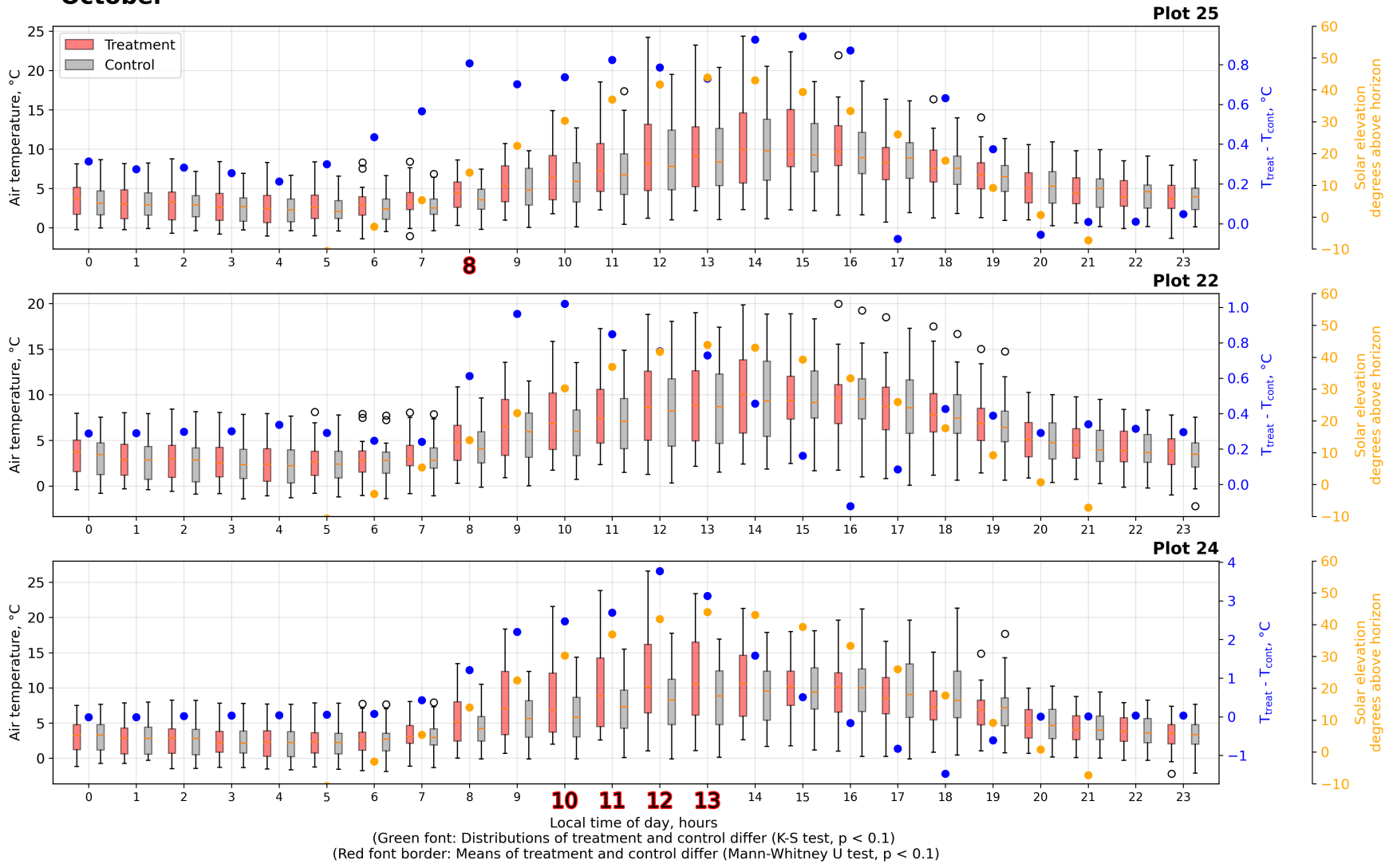

Figure S18. Average diurnal air temperature $\left(1 \mathrm{~cm}\right.$ above canopy) cycle at the treatment $\left(\mathrm{T}_{\text {treat }}\right)$ and control $\left(\mathrm{T}_{\text {cont }}\right)$ plots in October 2018. 
November
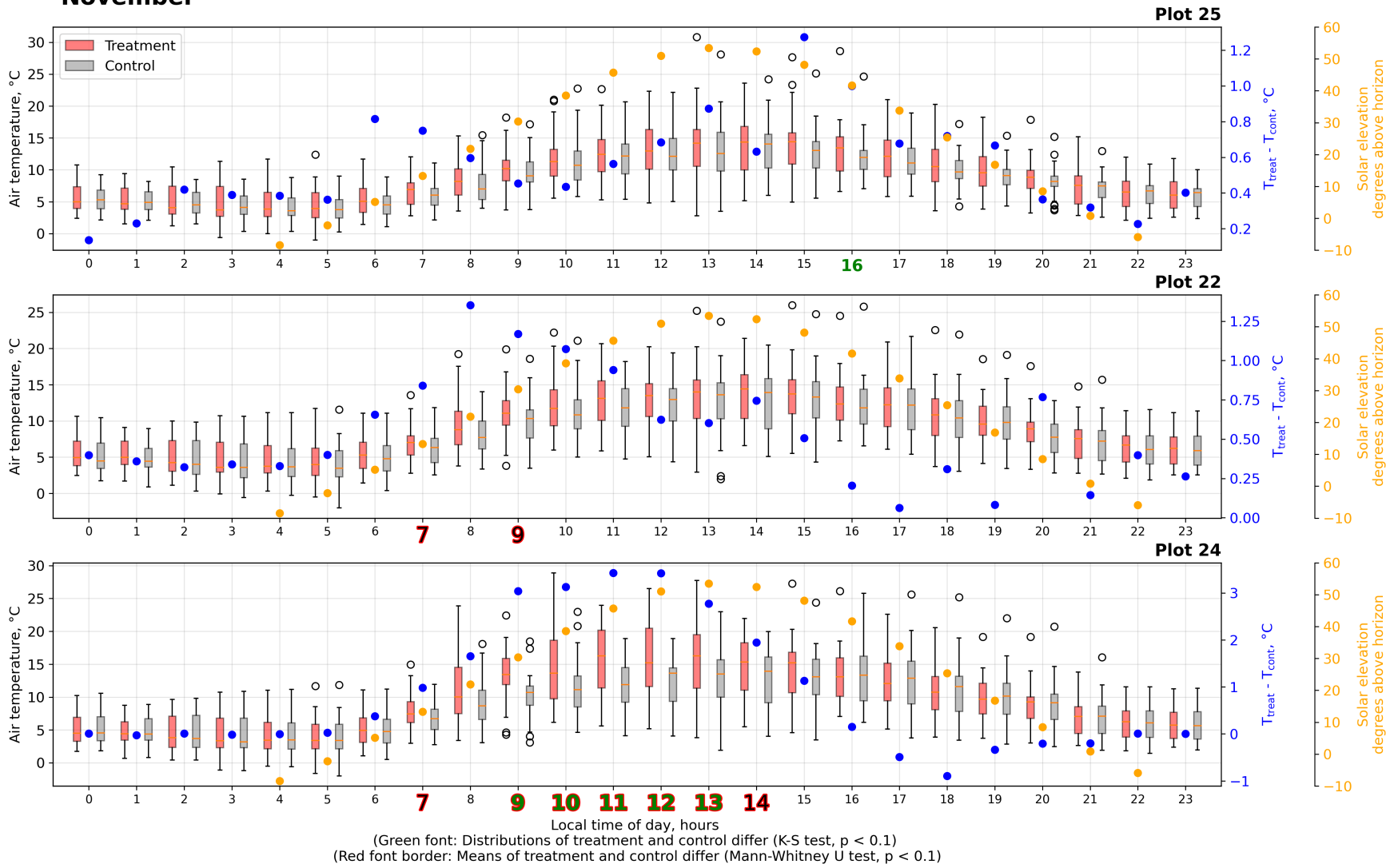

Figure S19. Average diurnal air temperature $\left(1 \mathrm{~cm}\right.$ above canopy) cycle at the treatment $\left(\mathrm{T}_{\text {treat }}\right)$ and control $\left(\mathrm{T}_{\text {cont }}\right)$ plots in November 2018. 
December
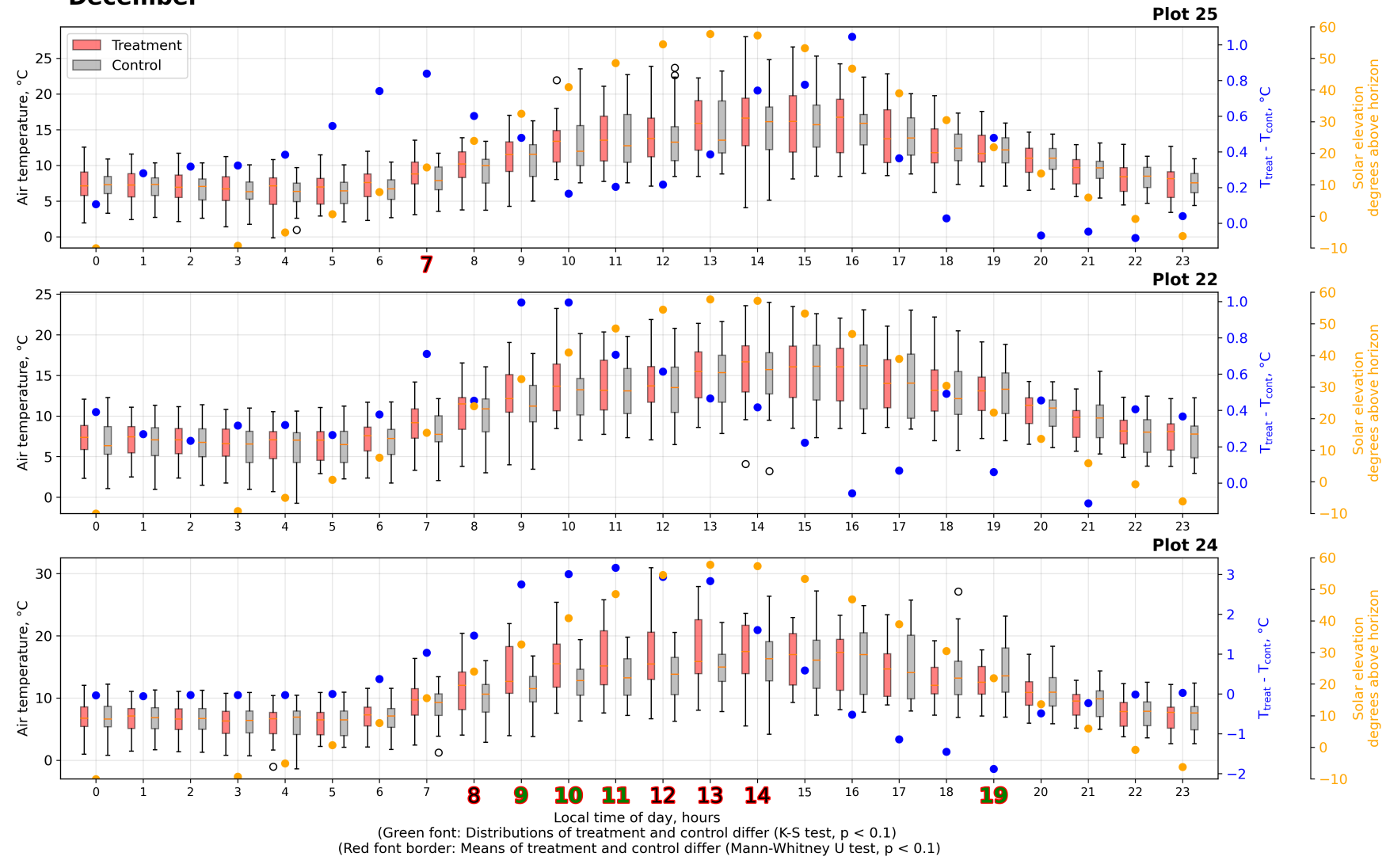

Figure S20. Average diurnal air temperature $\left(1 \mathrm{~cm}\right.$ above canopy) cycle at the treatment $\left(\mathrm{T}_{\text {treat }}\right)$ and control $\left(\mathrm{T}_{\text {cont }}\right)$ plots in December 2018. 


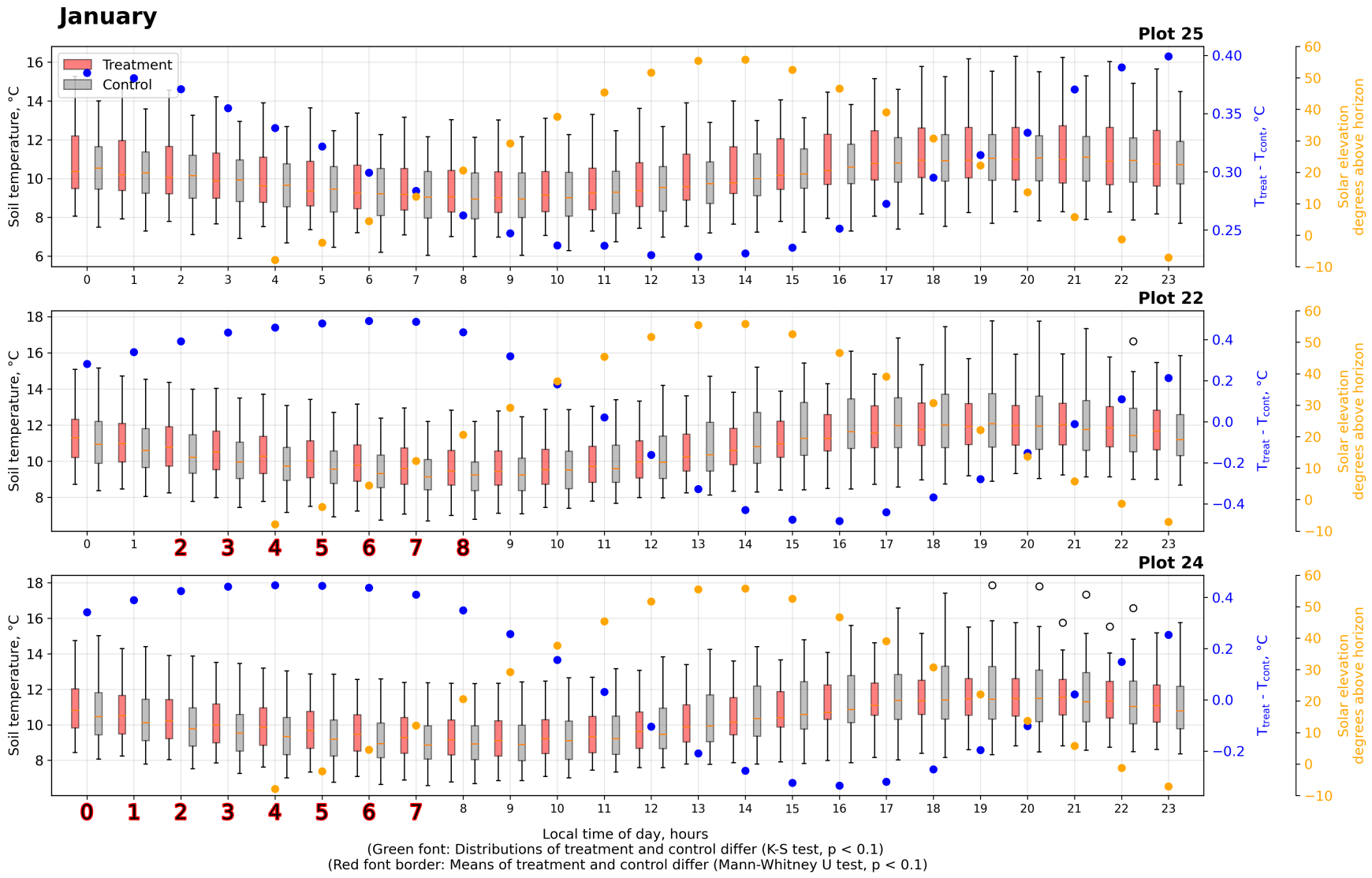

Figure S21. Average diurnal soil temperature $(10 \mathrm{~cm}$ depth $)$ cycle at the treatment $\left(\mathrm{T}_{\text {treat }}\right)$ and control $\left(\mathrm{T}_{\text {cont }}\right)$ plots in January 2018 and January 2019. 
February
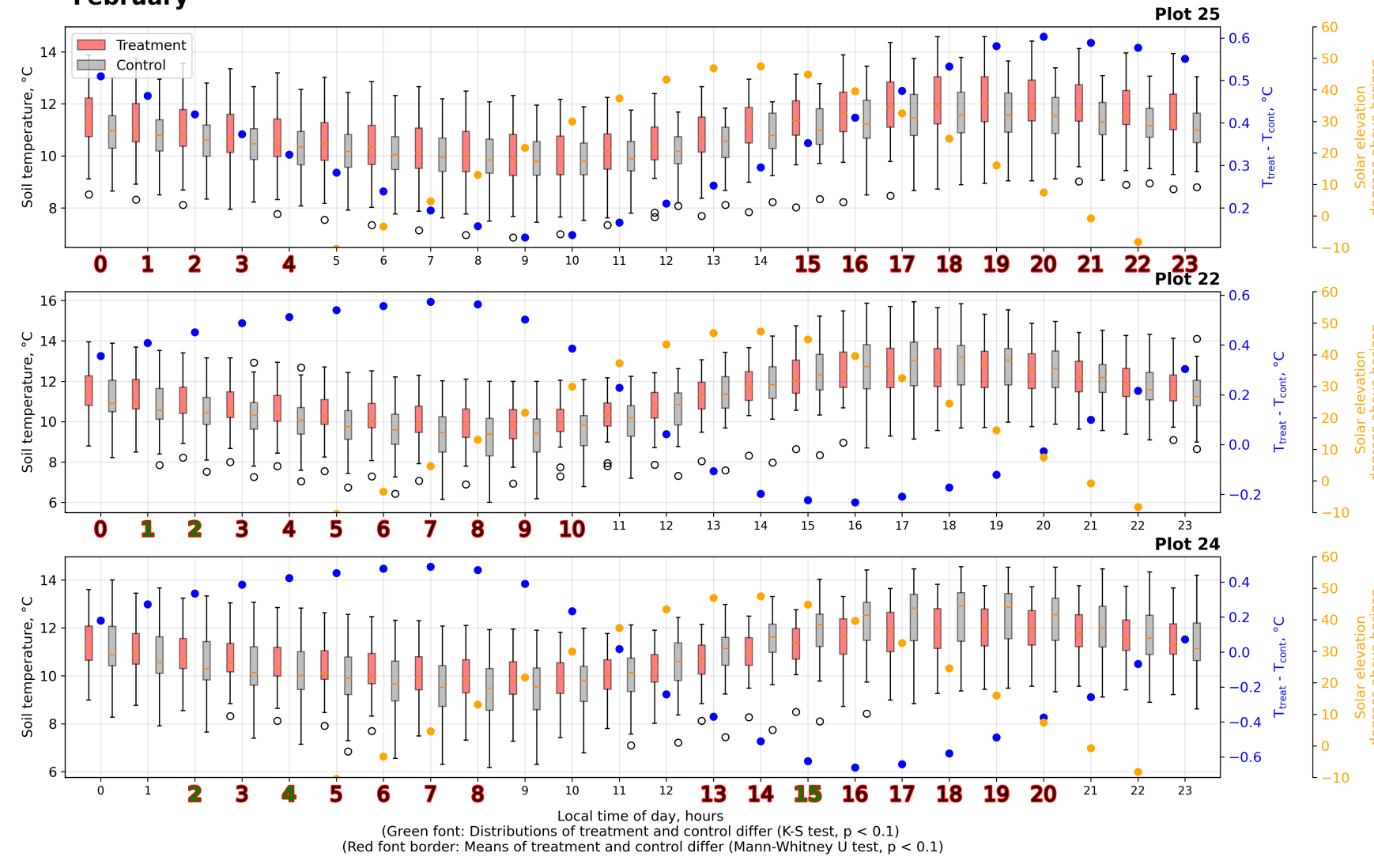

Figure S22. Average diurnal soil temperature $\left(10 \mathrm{~cm}\right.$ depth) cycle at the treatment $\left(\mathrm{T}_{\text {treat }}\right)$ and control $\left(\mathrm{T}_{\text {cont }}\right)$ plots in February 2018. 

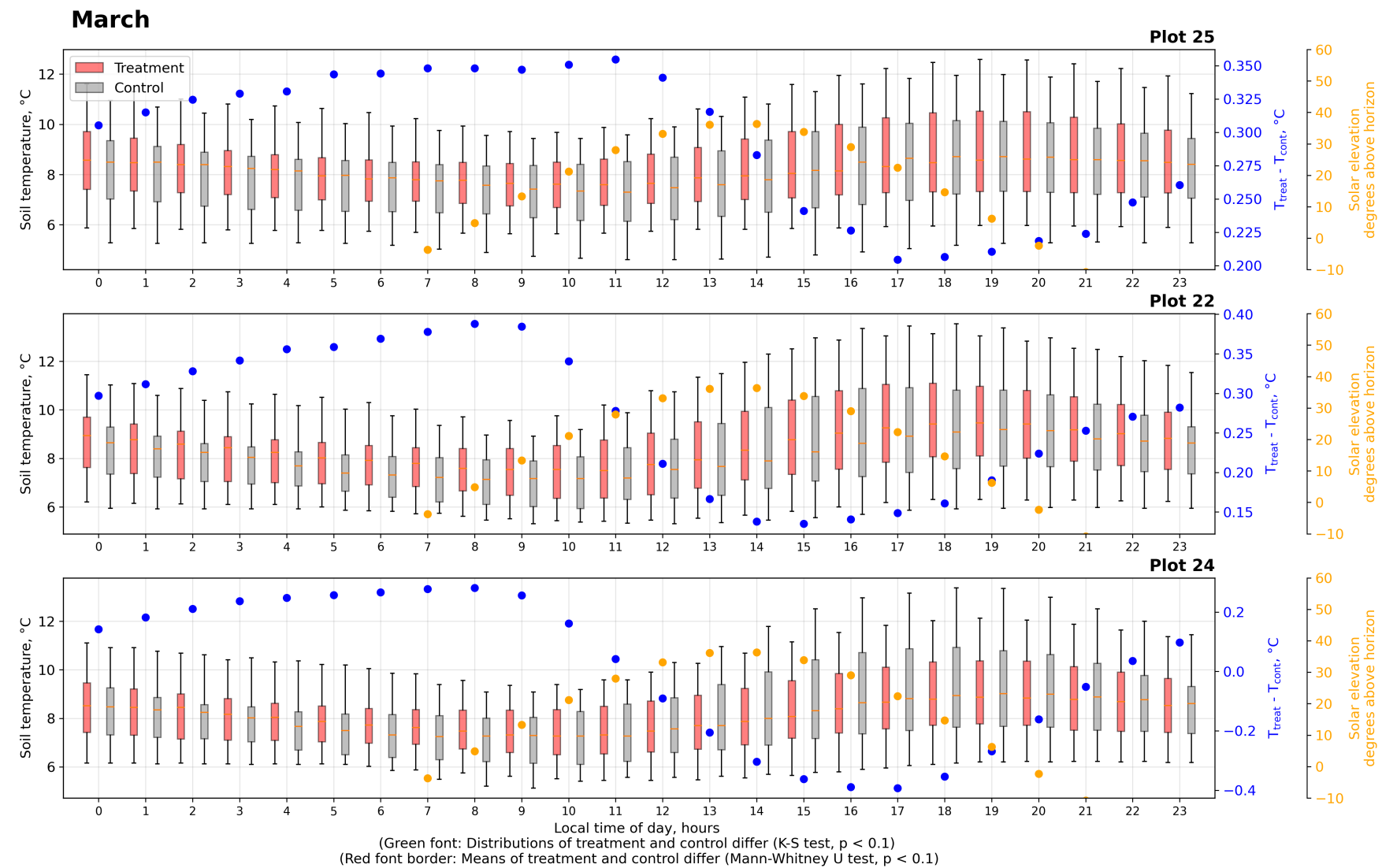

Figure S23. Average diurnal soil temperature $\left(10 \mathrm{~cm}\right.$ depth) cycle at the treatment $\left(\mathrm{T}_{\text {treat }}\right)$ and control $\left(\mathrm{T}_{\text {cont }}\right)$ plots in March 2018. 


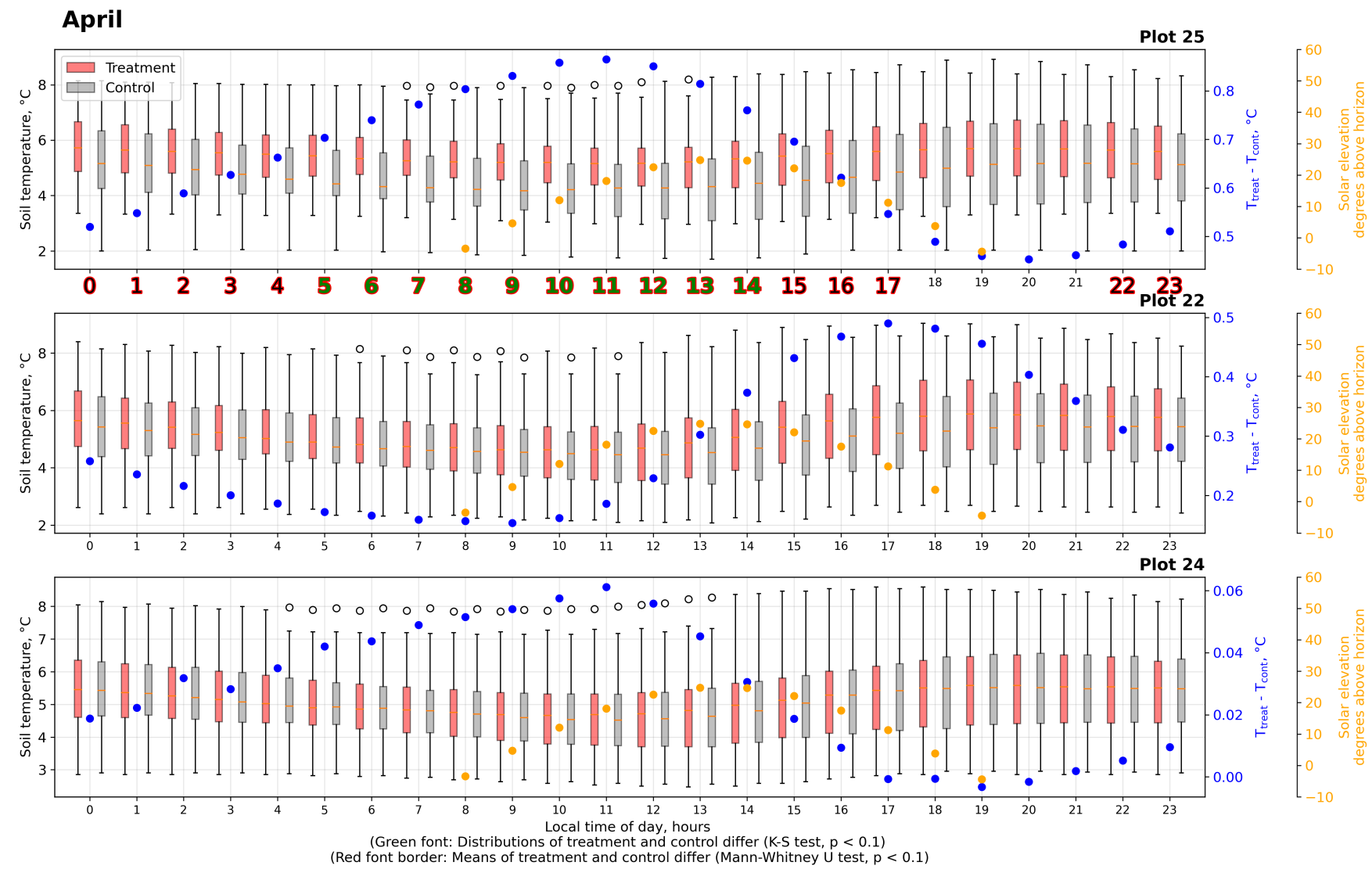

Figure S24. Average diurnal soil temperature $\left(10 \mathrm{~cm}\right.$ depth) cycle at the treatment $\left(\mathrm{T}_{\text {treat }}\right)$ and control $\left(\mathrm{T}_{\text {cont }}\right)$ plots in April 2018. 


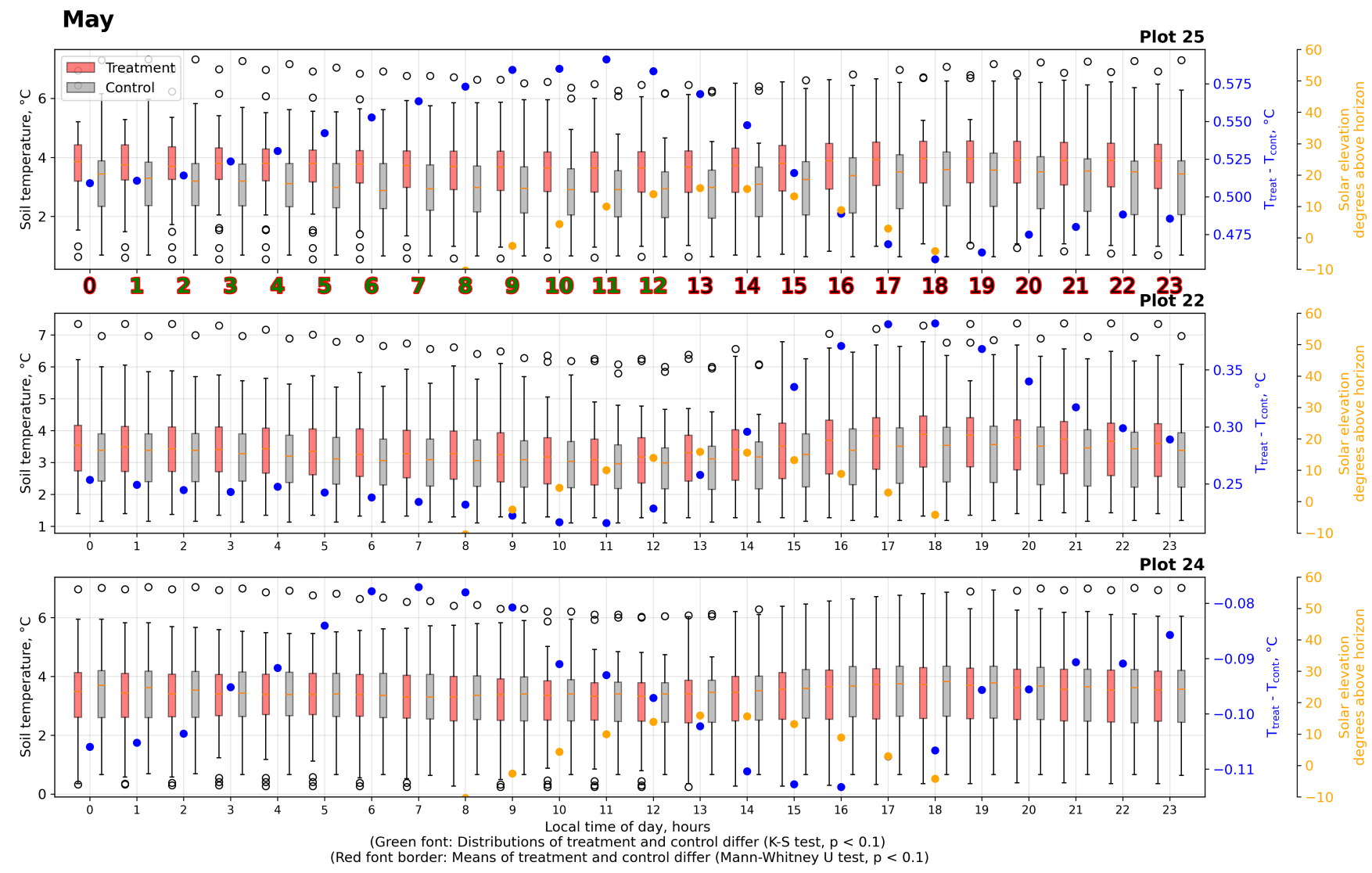

Figure S25. Average diurnal soil temperature $\left(10 \mathrm{~cm}\right.$ depth) cycle at the treatment $\left(\mathrm{T}_{\text {treat }}\right)$ and control ( $\left.\mathrm{T}_{\text {cont }}\right)$ plots in May 2018. 


\section{June}
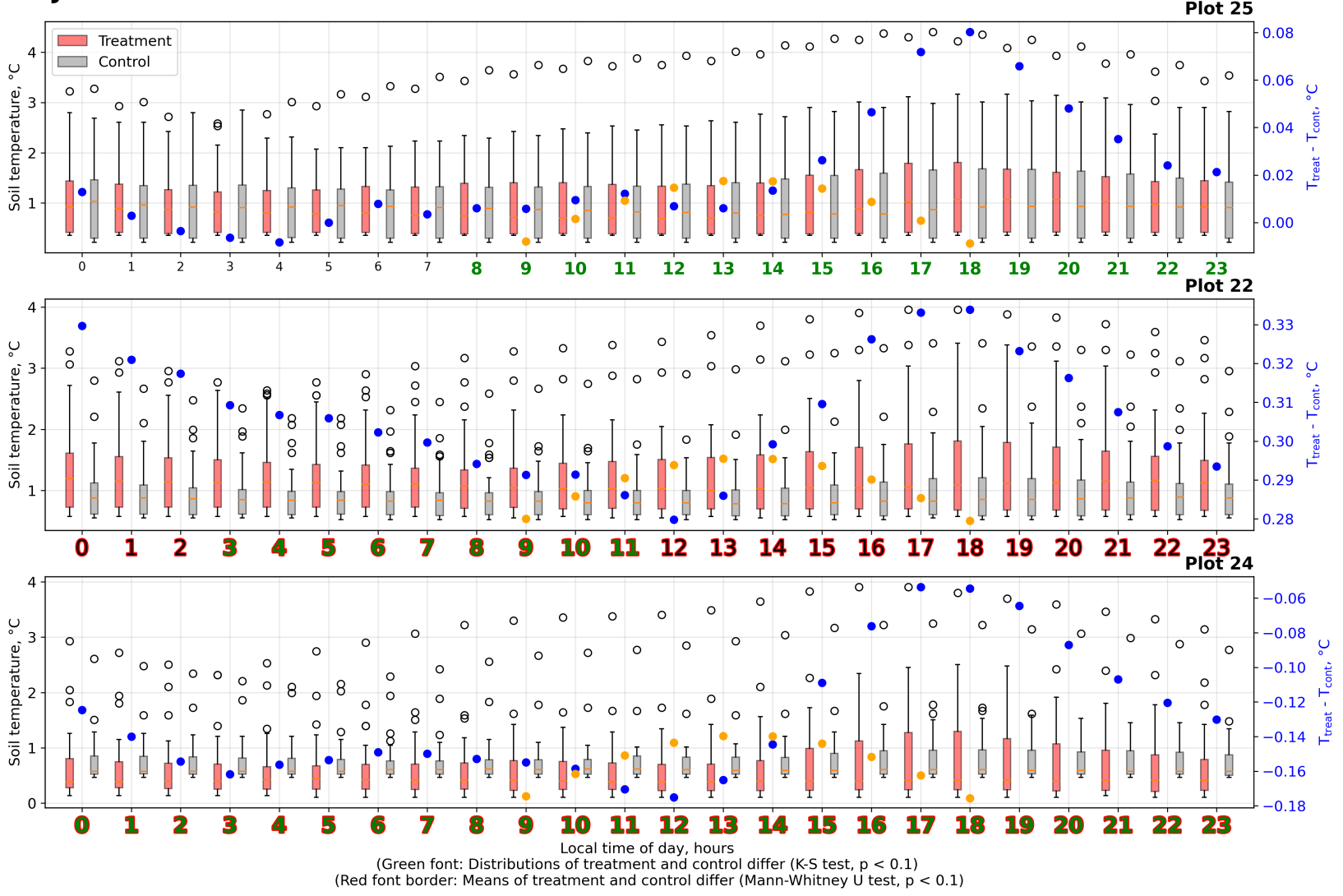

Figure S26. Average diurnal soil temperature $\left(10 \mathrm{~cm}\right.$ depth) cycle at the treatment $\left(\mathrm{T}_{\text {treat }}\right)$ and control $\left(\mathrm{T}_{\text {cont }}\right)$ plots in June 2018. 

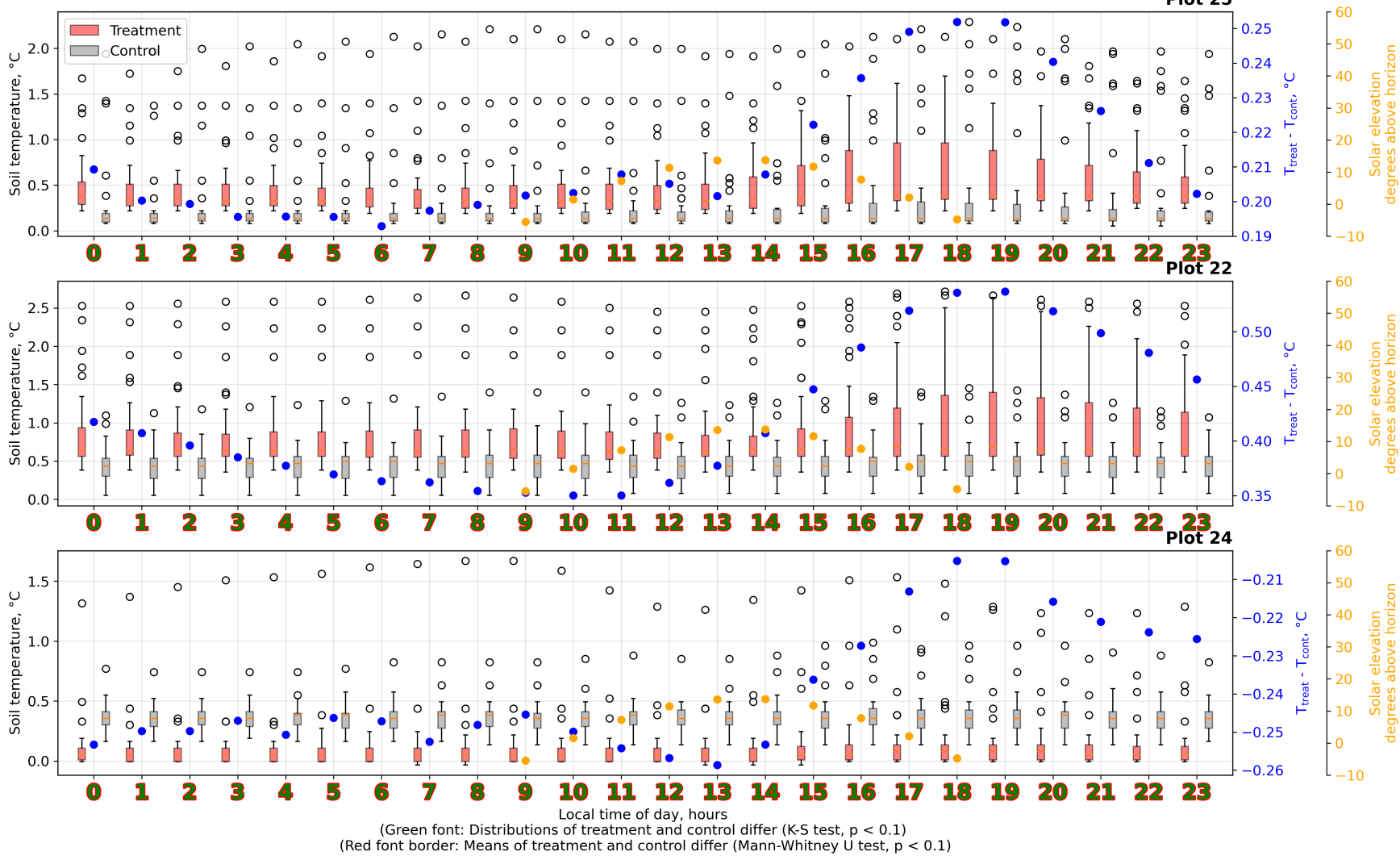

Figure S27. Average diurnal soil temperature $\left(10 \mathrm{~cm}\right.$ depth) cycle at the treatment $\left(\mathrm{T}_{\text {treat }}\right)$ and control $\left(\mathrm{T}_{\text {cont }}\right)$ plots in July 2018. 


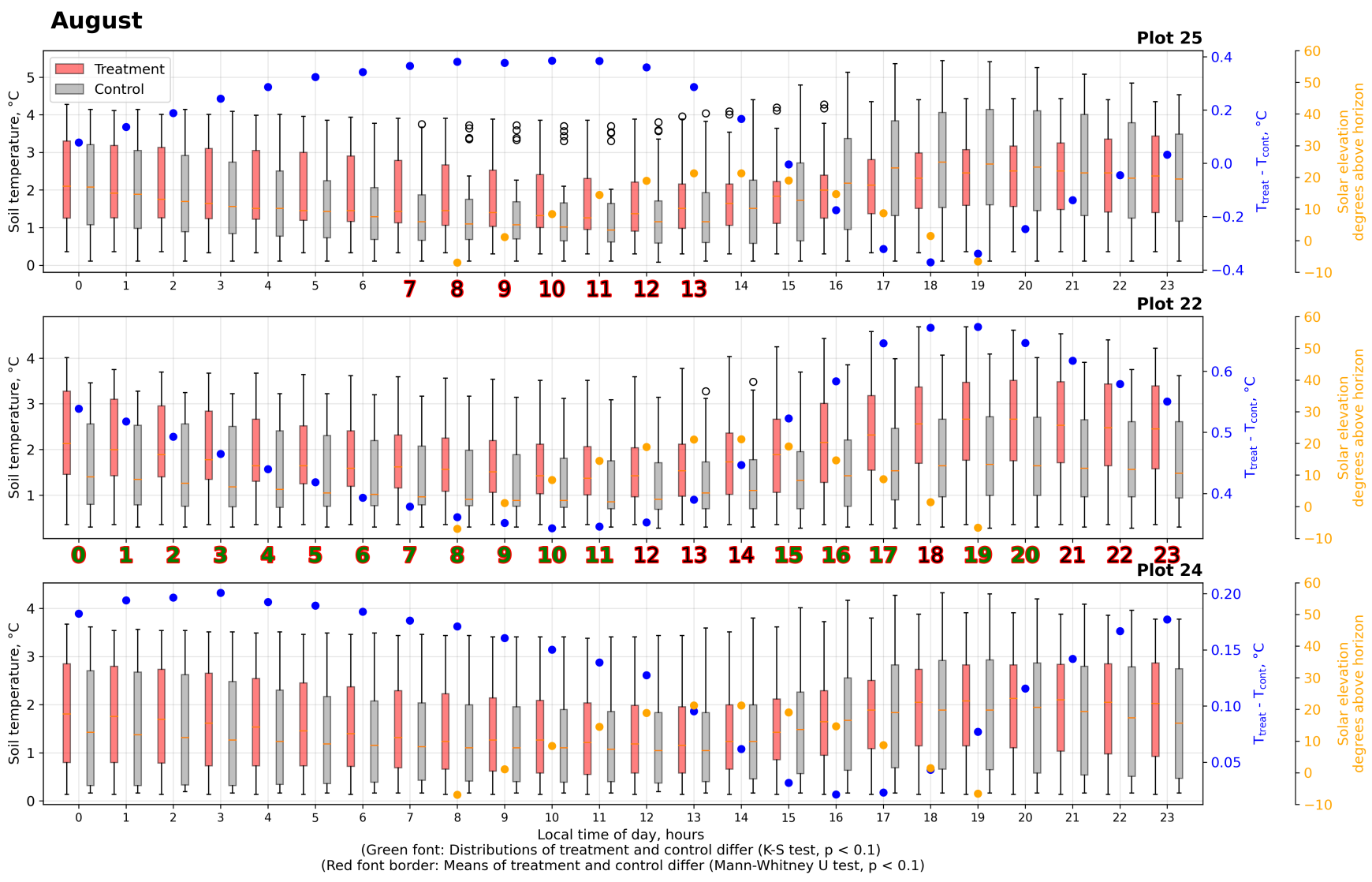

Figure S28. Average diurnal soil temperature $\left(10 \mathrm{~cm}\right.$ depth) cycle at the treatment $\left(\mathrm{T}_{\text {treat }}\right)$ and control ( $\left.\mathrm{T}_{\text {cont }}\right)$ plots in August 2018. 


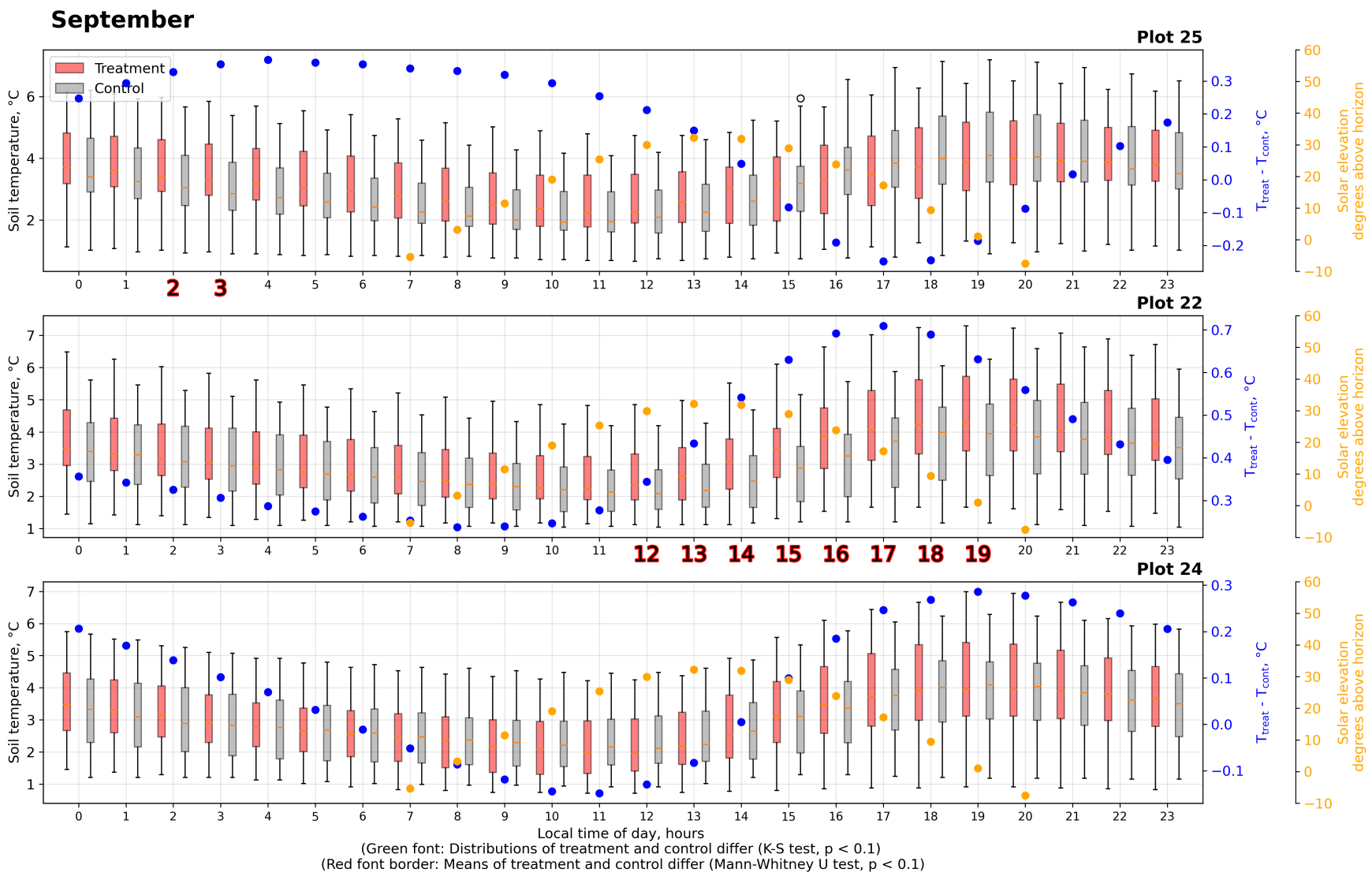

Figure S29. Average diurnal soil temperature $\left(10 \mathrm{~cm}\right.$ depth) cycle at the treatment $\left(\mathrm{T}_{\text {treat }}\right)$ and control $\left(\mathrm{T}_{\text {cont }}\right)$ plots in September 2018. 

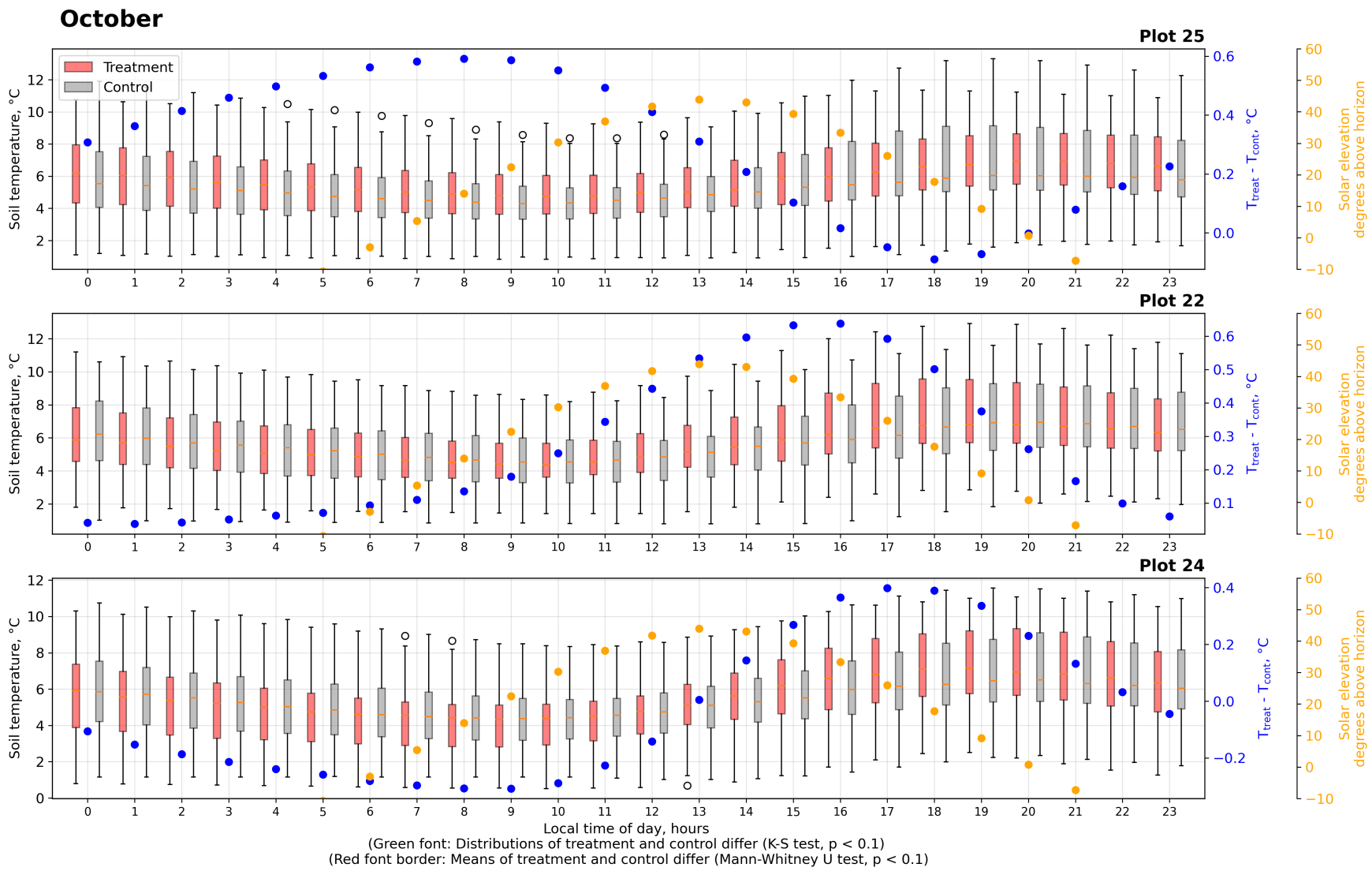

Figure S30. Average diurnal soil temperature $\left(10 \mathrm{~cm}\right.$ depth) cycle at the treatment $\left(\mathrm{T}_{\text {treat }}\right)$ and control ( $\left.\mathrm{T}_{\text {cont }}\right)$ plots in October 2018. 


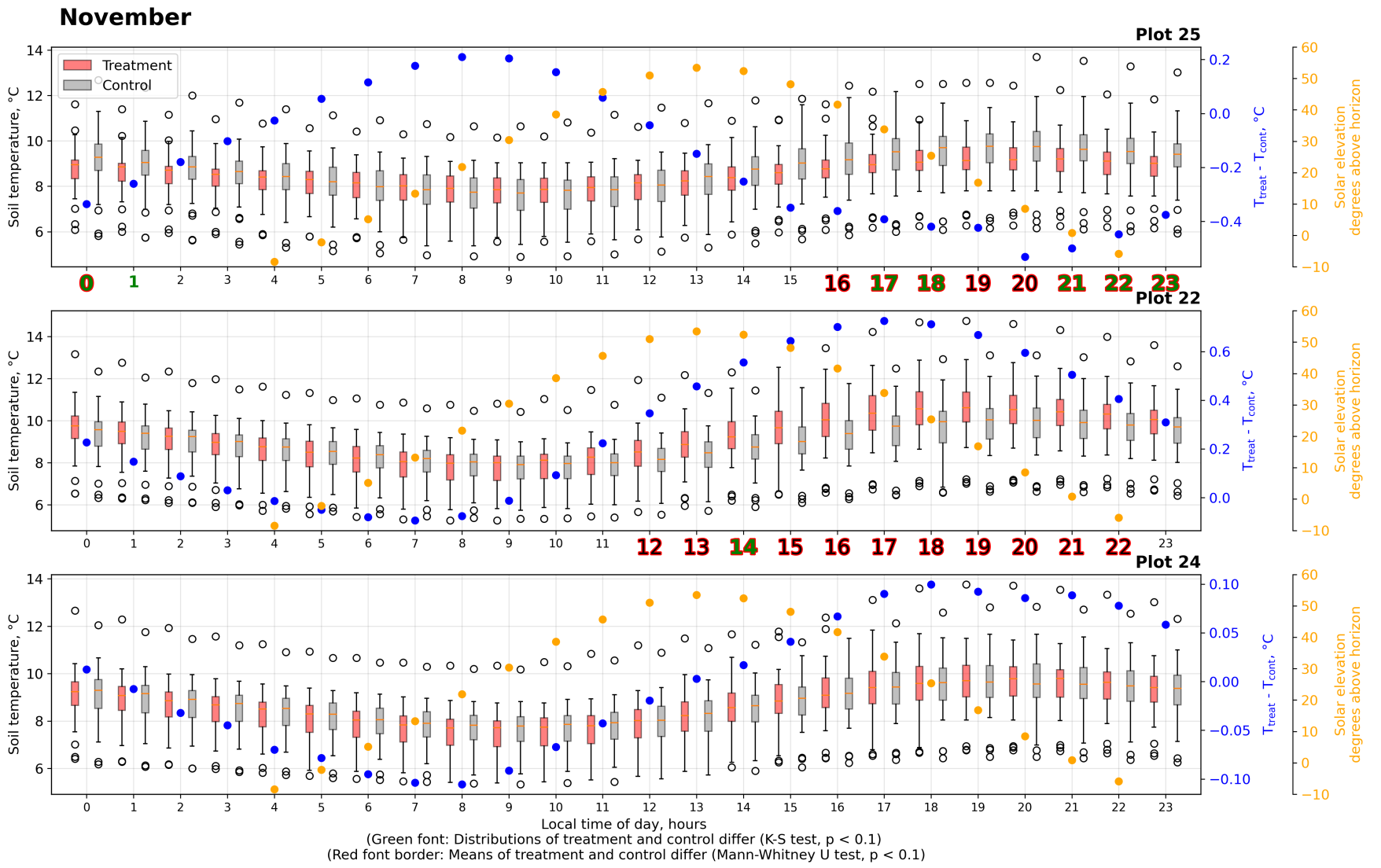

Figure S31. Average diurnal soil temperature $\left(10 \mathrm{~cm}\right.$ depth) cycle at the treatment $\left(\mathrm{T}_{\text {treat }}\right)$ and control $\left(\mathrm{T}_{\text {cont }}\right)$ plots in November 2018. 

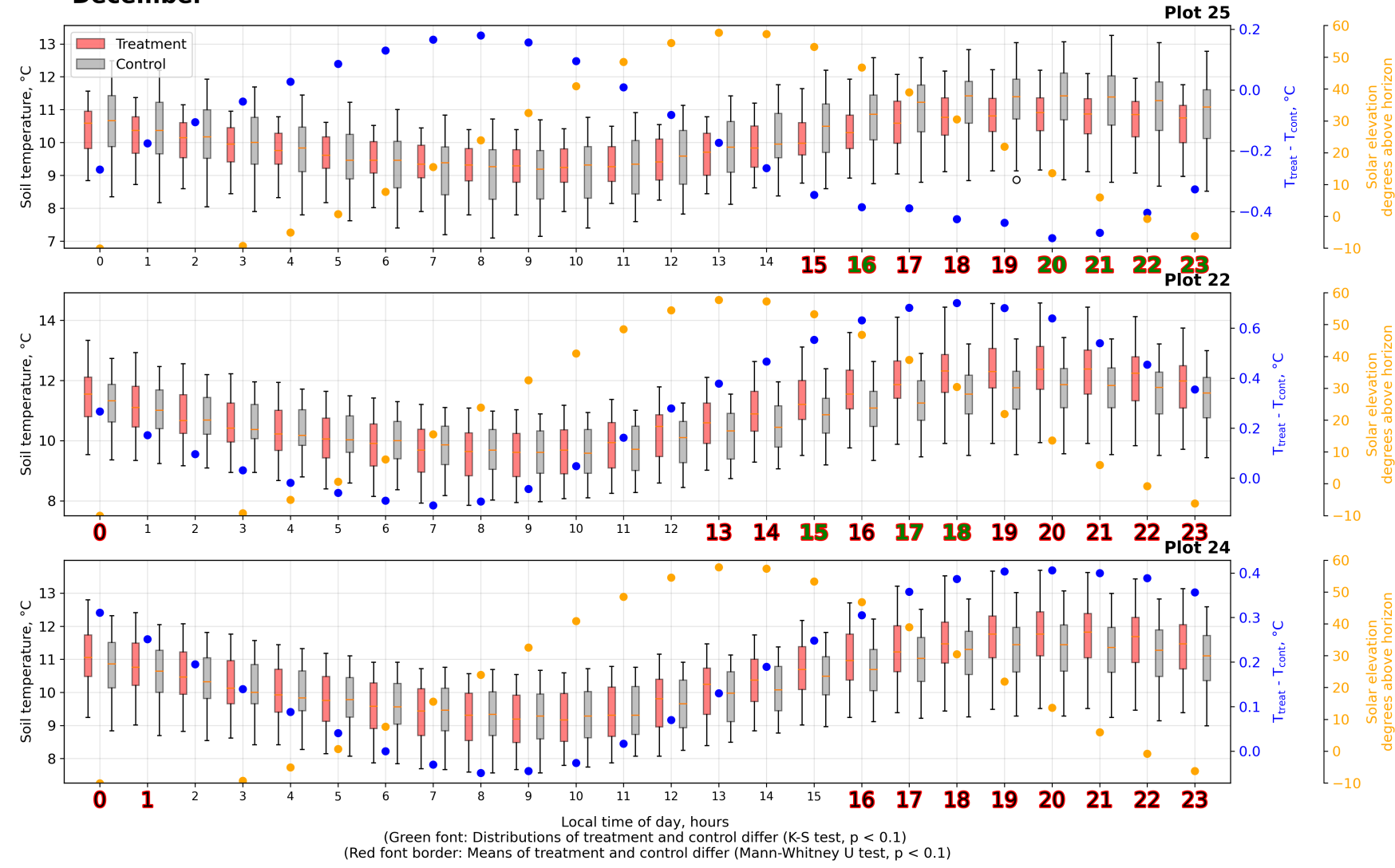

Figure S32. Average diurnal soil temperature $\left(10 \mathrm{~cm}\right.$ depth) cycle at the treatment $\left(\mathrm{T}_{\text {treat }}\right)$ and control $\left(\mathrm{T}_{\text {cont }}\right)$ plots in December 2018. 


\section{Investigation of wind shelter effects}

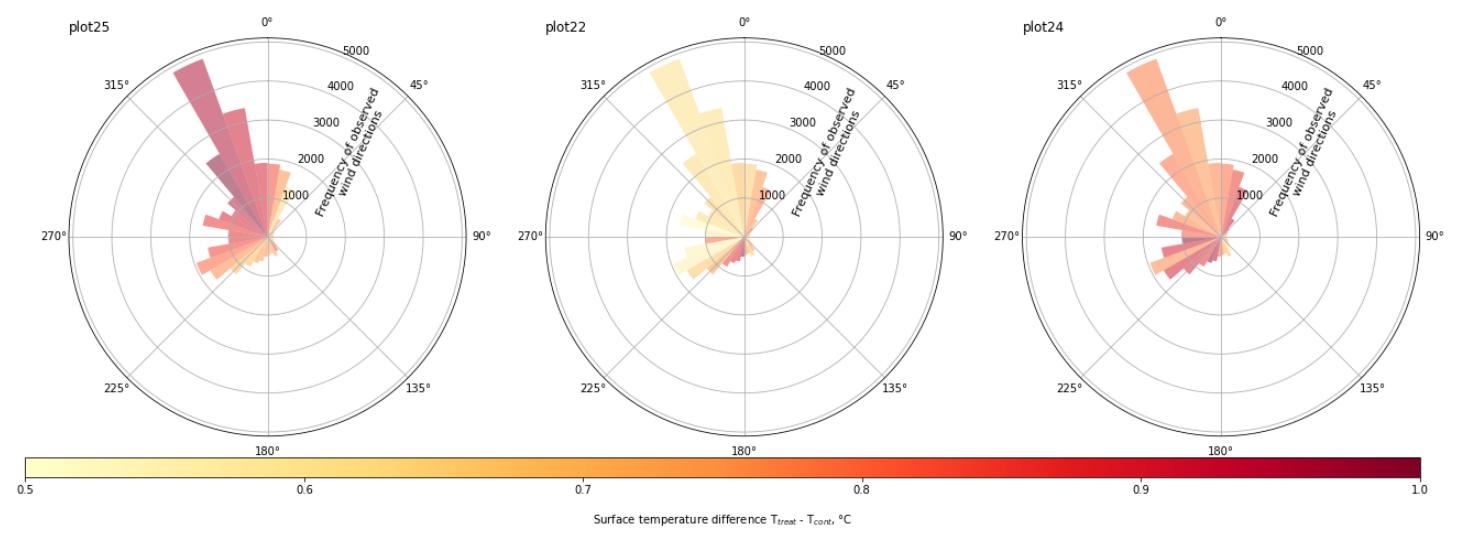

Figure S33. Polar histograms showing the frequency of wind directions as measured at the nearby eddy covariance station between January 2018 and January 2019 colored by the difference of observed surface temperatures inside $\left(\mathrm{T}_{\text {treat }}\right)$ and outside $\left(\mathrm{T}_{\text {cont }}\right)$ the three replicate plots where temperature sensors were deployed. Wind sheltering effect and thereby enhanced warming during phases of southern wind directions are not noticable consistently across the replicates. At plot 25 for example, the most efficient warming was archieved during phases of north-northwestern winds. 


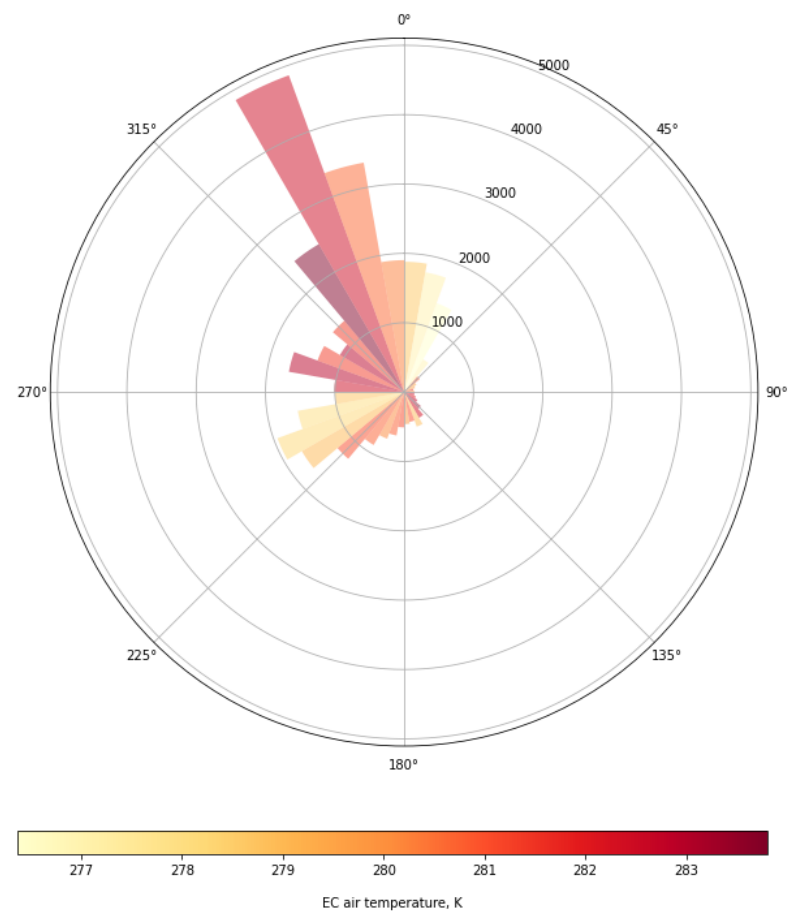

Figure S34. Polar histograms showing the frequency of wind directions as measured at the nearby eddy covariance station between January 2018 and January 2019. The color indicates $2 \mathrm{~m}$ air temperature measured at the same station. 